\title{
DONOS DEMAIS: MAESTRIA E DOMÍNIO NA AMAZÔNIA*
}

Carlos Fausto

Para Lévi-Strauss, em seu centésimo aniversário

Este texto versa sobre certa categoria indígena - usualmente traduzida por "dono" ou "mestre" - que, na Amazônia, transcende em muito a simples expressão de uma relação de propriedade ou domínio. A categoria e seus recíprocos designam um modo generalizado de relação, que é constituinte da socialidade amazônica e caracteriza interações entre humanos, entre não-humanos, entre humanos e não-humanos e entre pessoas e coisas. Entendo tratar-se de uma categoria-chave para a compreensão da sociologia e da cosmologia indígenas que, não obstante, recebeu relativamente pouca atenção. Há quase três décadas, Seeger chamava-nos a atenção para este fato: "O conceito de dono-controlador permeia a sociedade Suyá, embora haja relativamente pouca propriedade no sentido material da palavra [...] Seria, porém, uma falácia etnocêntrica manter que a posse [ownership] e a propriedade [property] são desimportantes" (1981:181-2).

As razões deste relativo esquecimento são complexas. De modo geral, vinculam-se a uma visão bastante comum sobre as terras baixas da América do Sul como uma província da igualdade e da simetria, em contraste com a hierarquia e a assimetria reinantes no Velho Mundo e no altiplano andino. Essa concepção horizontal das relações sociais pensadas ora sob o signo da igualdade sociopolítica, ora sob o signo da reciprocidade simétrica - marcou a literatura desde os cronistas até a etnologia moderna. A noção de dono insere-se de modo incômodo nesse imaginário não apenas pelo caráter assimétrico da relação que a define, mas também por poder evocar a propriedade privada. Em conseqüência, a relação de maestria-domínio acabou sendo relegada às notas de rodapé das etnografias ou reduzida a uma simples categoria ontológica, a dos donos ou mestres da natureza. 
Este texto visa mostrar, ao contrário, que a relação de maestria é tão central à compreensão das sociocosmologias indígenas quanto a de afinidade. Retomo aqui um tema que busquei enfrentar, há cerca de dez anos, a partir da noção de predação familiarizante - esquema pelo qual relações predatórias convertem-se em relações assimétricas de controle e proteção (Fausto 1997). Agora, procuro imaginar o universo ameríndio como um mundo de donos e o dono como o modelo da pessoa magnificada capaz de ação eficaz sobre esse mundo.

Antes de desenvolver estas idéias, é mister convencer o leitor da difusão e da centralidade das noções indígenas de dono-mestre na Amazônia.

\section{A categoria dono-mestre}

Até onde eu saiba, todas as línguas amazônicas possuem um termo - bastante estável historicamente - que designa uma posição que envolve controle e/ou proteção, engendramento e/ou posse, e que se aplica a relações entre pessoas (humanas ou não-humanas) e entre pessoas e coisas (tangíveis ou intangíveis). Esse termo tem grande produtividade e seu espectro de aplicação é amplo. Cito alguns exemplos, começando pelos Suyá, povo jê do Brasil Central, com os quais abri este texto.

Segundo Seeger, para os Suyá "a maioria das coisas tem donos-controladores: aldeias, cerimônias, cantos, casas, roças, bens, animais de estimação e assim por diante. A importância de kande é bem difusa" (1981:182). O termo kande ("dono-controlador") aplica-se não apenas à posse de bens tangíveis e intangíveis (como o conhecimento ritual), mas também à habilidade potencial para produzi-los. Ele forma ainda expressões para designar funções de prestígio e poder político: assim, os líderes beligerantes eram denominados weropakande, "donos de nossa aldeia", enquanto o especialista ritual é conhecido como mërokïnkande. Seeger afirma que kande é "o conceito mais importante no pensamento suyá sobre poder" (1981:181).

No sistema multilíngüe do Alto Xingu, a categoria é também de notável importância. Viveiros de Castro (2002a:82-3) afirma tratar-se "de uma noção fundamental da cultura xinguana", que se aplica a um grande número de contextos e que tem, no vínculo de paternidade, o seu modelo concreto. No caso yawalapiti, wököti designa o patrono ritual, o mestre especialista de cantos, o senhor de espécies animais ou vegetais, o chefe representante, ou o proprietário em sentido ordinário. ${ }^{1}$ Em todas essas denotações, está se definindo a relação de um sujeito com um recurso: o dono seria o mediador entre esse recurso e o coletivo ao qual pertence. 
Entre os Kuikuro, povo de língua karib da região, a categoria oto aplica-se ao mesmo campo semântico e tem também como esquema de base a filiação. Esta relação, que envolve controle e proteção, é marcada pela oferta alimentar: os pais são "nossos donos" (kukoto), pois cuidam de nós e nos alimentam. De mesmo modo, ser dono de estruturas coletivas - há donos do caminho (ama oto), da casa dos homens (kuakutu oto), da praça central (hugogó oto), da aldeia (eté oto) - implica cuidado, pois cabe ao dono manter essas estruturas e alimentar as pessoas que trabalham para esse fim. Ser dono representa prestígio e responsabilidade: os patronos de rituais tornam-se pessoas públicas por alimentarem a coletividade humana e os espíritos-donos das festas, que são considerados seus "filhos". A categoria dono-mestre aplica-se ainda aos depositários de conhecimentos intangíveis: os especialistas rituais são "mestres do canto" (eginhoto), os rezadores são "mestres de reza" (kehege oto), os feiticeiros são "mestres do feitiço" (kugihe oto) e assim por diante.

Os Trio são, como os Kuikuro, um povo de língua karib que habita a região de fronteira entre o Brasil e a Venezuela. O cognato de oto é entu que, segundo Brightman, "não tem equivalente direto em inglês, mas possui o sentido tanto de 'dono' como de 'patrão'" (2007:83). Ele não se aplica a qualquer relação de posse, mas sim ao que o autor denomina temporary controlled possession. O fundador e líder de uma aldeia é seu pata entu, assim como aquele que controla o funcionamento do rádio comunicador é radio entu. Entu significa ainda "tronco de árvore" e "piemonte", cujos traços semânticos "estar na origem de" e "ser a base de" aparecem também em outros contextos etnográficos.

Entre os Tupi-Guarani, os termos vernaculares para a categoria "dono" são cognatos de *jar e são bem conhecidos desde o século XVI. O araweté ña conota, segundo Viveiros de Castro, noções tais como "liderança, controle, representação e propriedade de certo recurso ou domínio" (1992:345). Entre os Parakanã, o recíproco mais comum de -jara é "animal de estimação" (enquanto no Alto Xingu, como vimos, é "filho"): o esquema concreto da relação de domínio é a familiarização dos filhotes de presas animais (Fausto 2001a:347-8). Isto é válido também para outros povos tupi-guarani, como os Wayãpi, para os quais "todos os jar têm 'sua criação', que tratam como eima, seus xerimbabos" (Gallois 1988:98). O termo, aliás, já era utilizado por Hans Staden no século XVI, ao relatar a primeira noite após sua captura, quando os Tupinambá lhe disseram: xé remimbaba in dé, "tu és meu animal prisioneiro" (1974 [1557]:84).

Nas línguas pano da Amazônia Ocidental, há cognatos muito similares para designar o dono-mestre. Em sharanahua, ifo designa o genitor em 
relação a seus filhos, o chefe em relação ao seu pessoal, o proprietário em relação aos objetos de sua posse, o dono em relação aos animais domésticos. Para Déléage (2005:189-91), os traços semânticos do termo incluem autoridade, gênese e comensalidade. O dono está na origem daquilo que possui, pois o fabricou, seja este artefato pessoa ou coisa: na Amazônia, a noção de fabricação não se aplica apenas aos objetos, mas também aos corpos de parentes e de animais familiares. Ifo designa ainda um tipo de entidade: os mestres de animais e vegetais com os quais os xamãs interagem.

Essa categoria de dono-mestre é extremamente difundida na região e corresponde ao que Hultkrantz (1961) denominou the supernatural owners of nature. Até recentemente, a literatura restringiu-se a essas figuras ao falar de donos ou mestres, apresentando-as como hipérboles da espécie que representam ou a forma antropomórfica pela qual se apresentam aos xamãs. A despeito de sua importância, é preciso reinserir essas figuras no conjunto das relações de maestria-domínio, pois como nota Cesarino a propósito de outro povo de língua pano, os donos dos animais "replicam a mesma configuração que caracteriza os donos de maloca (shovõ ivo) marubo: ambos são chefes de suas casas, nas quais habitam com suas famílias e seus costumes [...]" (2008:25). Os mestres dos animais, portanto, são donos em seu próprio meio, contendo em si um coletivo: eles representam e contêm uma espécie.

Entre os Kanamari, povo de língua katukina da Amazônia ocidental, a recursividade é o principal traço da categoria -warah, que designa o dono, o chefe, o corpo, o tronco, o rio principal. ${ }^{2}$ Luiz Costa enfatiza o caráter relacional da categoria: o termo é sempre afixado a um sujeito, de tal maneira que "uma pessoa sempre será 'chefe/corpo/dono' em relação a alguma coisa, a alguém ou a algumas pessoas" (2007:63). -Warah expressa uma relação continente-conteúdo, bem como singularidade-pluralidade, de tal modo que "o nome de uma pessoa seguido por -warah designa não apenas o corpo dessa pessoa, mas também, no caso de chefes, todos aqueles que chamam esta pessoa 'meu corpo-dono' ('meu chefe'), bem como todos os pertences da pessoa cujo nome forma a frase nominal 'X-warah' [...]" (Costa 2008:4). Esta estrutura replica-se em diferentes escalas: entre a alma e seu corpo, entre as pessoas e seu chefe, entre o chefe de aldeia e o chefe de uma área hidrográfica e assim por diante. O limite cósmico dessa relação é o Jaguar primordial que, no momento zero do cosmos, continha em seu corpo toda a pluralidade das diferentes singularidades virtualmente existentes. ${ }^{3}$

Quais são, enfim, os traços gerais da categoria dono-mestre que se podem extrair desses exemplos etnográficos? Antes de mais nada, é preciso deslocar a ênfase da categoria ontológica para a relação que ela implica (Déléage 2005:191). Mais do que explorar o conceito de dono-mestre na 
Amazônia, trata-se de analisar um esquema relacional que se aplica a inúmeros contextos. Se a categoria supõe uma relação, ela pede uma categoriarecíproca, a qual parece oscilar entre "filho" e "animal familiar", ambas tendo como traço subjacente a idéia de adoção. A relação modelar de maestria-domínio seria, pois, a filiação adotiva, relação que não é dada, mas constituída freqüentemente pela dinâmica que denominei predação familiarizante. Em outros trabalhos, forneci exemplos etnográficos da pregnância desse esquema relacional nos domínios do xamanismo, da guerra e do ritual, de tal modo que não creio necessário repeti-los aqui. É importante apenas reter que um mesmo esquema dá conta de relações tão distintas quanto aquela entre o xamã e os espíritos auxiliares, o guerreiro e a criança cativa, o matador e o espírito da vítima, o oficiante ritual e os objetos cerimoniais. ${ }^{4}$

Somando os resultados de trabalhos anteriores aos exemplos fornecidos neste texto, é possível afirmar que a relação de maestria-domínio:

a) aplica-se freqüentemente à posse de certos bens materiais (principalmente cerimoniais) e imateriais (em especial conhecimentos rituais);

b) não designa em todos os casos a relação pais-filhos, embora quase sempre se aplique à relação entre pais e filhos adotivos estrangeiros, em particular os cativos de guerra;

c) jamais se aplica aos inimigos vivos autônomos, mas pode designar a relação entre o matador e sua vítima após o homicídio;

d) tampouco se aplica aos animais de caça, embora designe a relação com os animais de estimação e, muito freqüentemente, a relação do pajé com os espíritos auxiliares;

e) aplica-se não poucas vezes à relação entre chefes e seguidores e, como veremos mais à frente, foi utilizado para designar novas relações no contexto da conquista e da colonização;

f) não se aplica apenas à relação entre humanos (ou humanos e não-humanos), mas designa relações internas ao mundo não-humano.

Um dos traços importantes da relação é a assimetria: os donos controlam e protegem suas criaturas, sendo responsáveis por seu bem-estar, reprodução, mobilidade. A assimetria implica não só controle, mas cuidado. Assim, o mestre dos animais entre os Chimane da Bolívia é definido como chojca-csi-ty, "aquele que os guarda, que toma conta deles, que zela por eles" (Daillant 2003:317). Da perspectiva de quem é adotado-cativado, estar ou pôr-se na posição de um órfão ou de um xerimbabo pode ser não apenas uma injunção negativa e inescapável, mas também um modo positivo, como veremos adiante, de reclamar atenção e generosidade. ${ }^{5}$ 
A assimetria da relação de maestria é muitas vezes concebida como uma forma de englobamento e pode se expressar como uma relação conteúdo-continente. Assim, por exemplo, os mestres dos animais costumam manter seus xerimbabos em um cercado ou em um recipiente, liberando-os paulatinamente para serem caçados pelos humanos. Teixeira-Pinto conta que um xamã arara explicou-lhe certa vez que os oto ("dono") de espécies animais guardam sua "criação" (iamït) em uma caixa, como um armário dos brancos (1997:97). ${ }^{6}$ Já para os Chimanes, o mestre mantém "seus animais em currais [...] fazendo-os sair, de vez em quando, por uma porta" (Daillant 2003:303).

Xamãs também conservam seus auxiliares em continentes. Alguns os guardam dentro de cestos e os alimentam com tabaco; outros os inserem, na forma de resinas ou pedras, no próprio corpo, passando literalmente a contêlos. Como exemplo, as lagartas õpi-wan wayãpi, auxiliares antropomorfos do xamã, estão dentro de seu corpo envoltas em minúsculas tipóias, assim como os xamãs estão envoltos nas teias que os ligam aos mestres dos animais (Gallois 1996:46-47). Este é também o caso dos dyohko kanamari, concreções de resina vegetal que são guardadas pelos xamãs em seus corpos, mas podem também ser postas em cestos, ser lançadas como dardos mágicos ou perambular pela mata na forma de jaguares (Costa 2007:381-383). É ainda o caso das pedras mágicas zápara alimentadas com tabaco pelo xamã, que as guarda em uma bolsa, mas que podem vir a ser incorporadas ao dono (Bilhaut 2007:57-61). A topologia é sempre complexa, pois os auxiliares dos xamãs aparecem, ao mesmo tempo, como partes internas e externas do dono-mestre. ${ }^{7}$

Essa topologia envolve também um jogo entre singularidade e pluralidade: o dono é uma singularidade plural, contendo em si, como um corpo (Costa 2007) ou uma maloca (Cesarino 2008), outras singularidades. O mestre é, assim, a forma pela qual uma pluralidade aparece como singularidade para outros. É nesse sentido que o chefe é um dono. Entre os Kuikuro, ao falar na praça central, o chefe só tem uma maneira para se referir aos habitantes de sua aldeia, independentemente do sexo ou da idade: "crianças" (kangamuke). Todas as outras distinções são obviadas para que ele apareça como uma singularidade inclusiva, uma pessoa magnificada (Heckenberger 2005:259-263). A forma-chefe - o corpo, o arco-na-mão e a fala-discurso comemorando uma história única do povo kuikuro (Franchetto 1993) — aparece aos olhos dos mensageiros de outras aldeias como um povo, um otomo (forma coletivizada do termo "dono"). Nesse sentido, mais do que um representante (i.e., alguém que está no lugar de), o chefe-mestre é a forma pela qual um coletivo se constitui enquanto imagem; é a forma de apresentação de uma singularidade para outros. ${ }^{8}$ 
A forma chefe-mestre, enquanto imagem singular de um coletivo, aplica-se também aos donos dos animais. O exemplo mais característico, pois expressa uma relação ecológica visível, é a figura do mestre dos pecaris. O mestre é aqui um chefe que contém um coletivo de porcos, tidos como seus filhos ou xerimbabos. Para que o mestre apareça como uma singularidade magnificada, o bando deve aparecer como uma coleção-anônima sem capacidade de ação própria. Daí porque afirmei alhures que o mestre representa a parte-jaguar, enquanto o bando representa a parte-caça, o aspecto passivo dos porcos (Fausto 2007:509). ${ }^{9} \mathrm{Na}$ Amazônia, toda singularidade magnificada aparece aos olhos dos outros como um predador, comumente como um jaguar, uma anaconda ou uma harpia.

O dono é, pois, uma figura biface: aos olhos de seus filhos-xerimbabos, ele é um pai protetor; aos olhos de outras espécies (em especial os humanos), ele é um afim predador. A jaguaricidade é um dos traços associados à figura do mestre na região. Mesmo o chefe alto-xinguano, moderado e não-agressivo, quando se apresenta ritualmente perante dignatários de outras aldeias, cobre-se de partes do corpo de um jaguar: cinto e chapéu feitos de seu couro, colar feito de suas unhas. Em sentido lato, todo mestre é um jaguar. E é fácil entender por quê: o dispositivo principal de produção de englobamento, portanto, de magnificação da pessoa, é a incorporação canibal. A predação é um vetor assimétrico de identificação-alteração: quem come contém o outro e a sua alteridade dentro de si.

\section{(In)dividualismo possessivo}

Espero ter deixado claro até aqui como as noções de dono e de domínio não podem faltar à nossa compreensão da Amazônia indígena. A ausência de propriedade privada sobre recursos materiais importantes bloqueou a imaginação conceitual a respeito de relações de maestria-domínio, como se o modelo por excelência da propriedade fosse o da propriedade privada exclusiva sobre bens, à qual corresponderia certo conatus consumista e expansivo. No caso ameríndio, porém, a posse de objetos deve ser vista como um caso particular da relação de domínio entre sujeitos, e o artefato-coisa como um caso particular do artefato-pessoa. Como afirma Sztutman, a maestria é "uma noção cosmológica que inflete sobre o plano sociopolítico, remetendo, em termos muitos gerais, a essa capacidade de 'conter' - apropriar-se ou dispor de - pessoas, coisas, propriedades e de constituir domínios, nichos, grupos" (2005:261).

Se as relações ameríndias de maestria-domínio não se confundem com as relações de propriedade tal qual costumamos concebê-la, como se 
comparam exatamente a elas? Como falar de donos e domínio sem reavivar o espectro do individualismo possessivo que boa parte da literatura antropológica contemporânea se dedica a conjurar? Não tenho espaço (nem fôlego) aqui para uma comparação exaustiva; por isso, concentro-me em um único autor, Locke, tomando-o como um dos modelos clássicos da relação de propriedade e do Self como proprietário. Trata-se de um exercício heurístico para iluminar um ponto do argumento, sem nenhuma pretensão de completude. ${ }^{10}$

Começo pelo duplo problema que enfrentava Locke ao refutar o absolutismo e o patriarcalismo adamita nos Dois tratados sobre o governo: de um lado, tratava-se de fundar a liberdade individual, portanto, os limites do governo; de outro, tratava-se de fundar a propriedade privada no direito natural, mesmo postulando um estado originário em que o mundo fora dado em comum a todos. A solução para ambos os problemas Locke encontra no conceito da propriedade de si, relação originária e exclusiva da pessoa consigo mesma que fornece, ao mesmo tempo, o fundamento da liberdade e da propriedade: "Ainda que a Terra e todas as Criaturas inferiores sejam comuns a todos os Homens, cada Homem tem uma Propriedade em sua própria Pessoa. A isto ninguém tem qualquer Direito, a exceção dele mesmo" (Locke 1988:287 - Bk. II, Ch.V, § 27).

Se a propriedade de si torna o arbítrio e a escravidão contrários à lei natural, como se passa então da auto-relação à relação entre pessoas e coisas? Como se estabelecem vínculos legítimos entre sujeito e objeto à exclusão de outros sujeitos? Para Locke, a extensão da propriedade de si a coisas se dá por meio do trabalho (labour). Os objetos são, por assim dizer, contaminados pela ação do corpo, ação esta que pertence exclusivamente ao agente e que retira as coisas do estado natural, anexando-as a si enquanto seu domínio privado. Esse raciocínio, conhecido como labour-mixing argument, implica que o trabalho mistura-se às coisas, agregando a elas algo que é próprio ao sujeito da ação (Locke 1988:288; Bk.II, Ch.V, § 27). ${ }^{11}$

A teoria lockiana da propriedade subtende uma teoria da identidade pessoal, pois é mister fundar o sujeito ao qual se atribui um direito originário sobre si mesmo. O que garante sua continuidade ao longo do tempo e do espaço? Como saber se ele é sempre o mesmo e não outro? Segundo Locke, a identidade pessoal funda-se na continuidade da consciência, na relação reflexiva consigo mesmo. Uma pessoa, diz ele, é "um ser pensante inteligente, que tem razão e reflexão, e pode considerar-se a si mesmo como si mesmo, a mesma coisa pensante em diferentes tempos e lugares" (1995:246 — Bk.II, Ch. XXVII, § 9). O próprio e a propriedade confundem-se aqui, pois ambos dependem de uma relação consigo mesmo, de uma auto- 
identidade. Mêmeté et ipseité, para usar o vocabulário de Ricouer (1990), tornam-se indissociáveis na construção da pessoa. O self deve ser idêntico a si mesmo ("the same thinking thing in different times and places") para que possa ser objeto de um juízo: sem identidade não há como construir o par responsabilidade moral e acountabilidade jurídica; sem reduzir a diferença a zero, não se funda a sociabilidade a partir de indivíduos apropriadores, livres porque proprietários de si mesmos.

Em resumo, a teoria da propriedade em Locke aciona uma série de pressupostos cosmológicos e antropológicos. Temos uma divindade que fabrica um mundo povoado por sujeitos (seres humanos) e coisas úteis (animais, plantas, terra...) dadas em comum para a humanidade. Esses sujeitos têm dois atributos principais: primeiro, uma identidade consigo mesmo que se mantém apesar da duração, e que é condição para que possam ser julgados (por Deus e pelos homens) em função de seus atos; segundo, são proprietários (causa) de seus atos, por serem também proprietários de seu próprio corpo, que é o meio através do qual tais atos têm eficácia sobre o mundo. A ação sobre o mundo - reunida na categoria "trabalho" (labour) — conduz progressivamente à apropriação das coisas úteis, de tal modo que aquilo que fora dado em comum passa a ser individuado e dominado por uns à exclusão dos outros. Na vida social, esse processo conduz a uma distinção entre proprietários e não-proprietários, sendo que os primeiros, graças ao domínio sobre coisas que se agregam ao seu corpo, passam a ter um excedente de agência. O proprietário torna-se, assim, o modelo do agente e os bens apropriados transformam-se em índices de sua capacidade agentiva.

Como uma narrativa indígena comparar-se-ia a essa narrativa lockiana de constituição da pessoa e da sociedade, da liberdade e da obrigação? Se fôssemos contá-la em chave ameríndia, qual o mundo que dela emergeria? É certo que as cosmologias indígenas acionam pressupostos bastante diferentes. Não o fazem, porém, por estarem desprovidas de uma concepção de domínio ou de um mecanismo de apropriação, e sim porque estes se erguem sobre princípios diversos. Em um esforço de imaginação conceitual, tentemos contar a mesma história de um outro ponto de vista.

\section{Um mundo de donos}

Na origem, o mundo não foi dado em comum aos humanos por uma divindade para que fosse apropriado. A ontologia do tempo mítico não estabelece duas grandes classes de seres: de um lado, sujeitos autônomos (proprietários de si); de outro, coisas apropriáveis (propriedades em potência). Não há parti- 
ção definitiva entre sujeitos e objetos. O mundo do mito é permeado por um fundo de continuidade subjetiva, um fluxo comunicacional envolvendo todos os existentes. Esse estado, ao contrário da identidade original à SubstânciaDeus, seria, como argumentou Viveiros de Castro (1998:41; 2007:51), um estado de diferenças infinitas, internas à pessoa, caracterizado pelo regime da metamorfose. Nesse estado primordial, a diferença está pressuposta, embora não ainda posta, pois o que o mito narra é precisamente a posição da diferença, i.e., a produção de descontinuidades entre as espécies, entre os coletivos humanos, entre o céu e a terra, entre o dia e a noite, entre as terras firmes e as águas que, em seu conjunto, irão constituir o mundo tal qual o conhecemos. São justamente os donos virtuais, seres com capacidade criativa e transformativa, que engendrarão-fabricarão, por meio de suas ações e de seus lapsos, o mundo pós-mítico.

As Primeiras Pessoas viviam - justamente como o fazem os xamãs hoje - em um estado polimorfo, no qual nenhuma fronteira existia. Era o tempo das origens (illud tempus), quando o Céu e a Terra estavam ainda conectados e as distinções entre espécies ainda não eram reconhecidas. Foi somente quando essas divisões se solidificaram que, por fim, as Primeiras Pessoas se retiraram da Terra, deixando suas formas para trás como resíduos do que fora o Tempo do Sonho. Após sua retirada da Terra, cada uma das Primeiras Pessoas tornou-se o "Mestre" ou arache das espécies que engendraram (Guss 1989:52).

Não são apenas os atributos "naturais" que se definem nesse processo de especiação; definem-se também os atributos "culturais" de cada espécie. Tal definição é, não raras vezes, proveniente da passagem de uma possedomínio a outra. Muitos dos mitos etiológicos indígenas narram menos uma origem-gênese do que o modo pelo qual atributos que irão caracterizar a sociabilidade humana foram apropriados de animais. O fogo culinário é o exemplo mais famoso: nos mitos tupi-guarani, o roubo do fogo que pertencia ao urubu faz com que os humanos se tornem comedores de carne cozida em oposição à necrofagia; nos mitos jê, o roubo do fogo do jaguar conduz à distinção entre a alimentação crua (canibal) e aquela cozida, capaz de produzir a identidade entre parentes (Fausto 2002a, 2007).

As narrativas jê são particularmente sugestivas para o argumento deste texto, pelo fato de o dinamismo transespecífico erguer-se sobre a filiação adotiva. De uma relação inicial entre cunhados passa-se à relação de familiarização entre o menino e o jaguar. ${ }^{12}$ Na versão Kayapó-Gorotire, "a fêmea do jaguar (que era uma Índia) não gosta do jovem rapaz, a quem ela chama de me-on-kra-tun ('filho estrangeiro' ou 'abandonado'); a despeito disto, o 
jaguar, que não tem filhos, decide adotá-lo" (Lévi-Strauss 1964:75). O pai adotivo sai todos os dias à caça para alimentar o filho, deixando-o a sós com uma antimãe. Para que possa se defender, o jaguar dá ao menino um arco e flecha, com o qual ele acaba por matar a esposa do pai adotivo. Em seguida, ele se apropria dos bens do jaguar: o arco, o fio de algodão e o fogo culinário (versão Kayapó-Kubenkranken). Ao recusar a adoção, o menino reinstala o estado de inimizade que marcará doravante a relação entre os jaguares e os humanos, e reconstitui os laços de parentesco com seus congêneres.

O mundo pós-mítico que surge dessa dinâmica inicial é um mundo de múltiplos domínios. Esses domínios são constitutivos da estrutura do cosmos, de tal modo que um dos pressupostos a reger a ação humana sobre o que chamaríamos de mundo natural é o de que tudo tem ou pode ter um dono. Como mostrou Descola (1986), a natureza é doméstica porque é sempre o domus de alguém. Para os Achuar, a floresta é a plantação de Shakaim, os animais selvagens são familiares das mães da caça, e as plantas cultivadas estão sob a tutela de Nunkui, mulher-espírito que está na origem dos cultivares. O mundo não-humano nem é de todos, nem tampouco é terra de ninguém. Como diriam os Kuikuro, não é tatutolo engü, "coisa de todos", o que equivale a dizer que não há ninguém para cuidar. ${ }^{13}$ É porque há donos zelosos que os Kuikuro, quando vão a uma pescaria coletiva, proferem uma longa encantação em que enunciam o nome de todos os donos da água e solicitam que não ajam de forma predatória contra os pescadores, nem escondam os seus peixes (Fausto, Franchetto \& Montagnani 2007). A encantação visa produzir uma disposição generosa nos donos, levando-os a abrir mão de seus preciosos bens.

Se o mundo indígena é um mundo de donos, qual é então a natureza de seus domínios? Referindo-se aos Guarani-Kaiowá, Mura sugere que:

do ponto de vista da tradição de conhecimento indígena, não é possível imaginar a existência de lugares, caminhos, seres vivos e inanimados, como neutros, autônomos, sem proprietários. No Cosmo atual todos os elementos que o compõem possuem donos, constituindo domínios e respondendo a uma lógica extremamente significativa no processo de hierarquização do Universo [...] (2006:234-235).

O mundo estaria, assim, dividido em domínios, em diferentes espaços de domesticidade pertencentes a humanos e a não-humanos, cada qual com os seus donos-mestres. Gallois (1984/1985) chega a sugerir, para os Wayãpi, a existência de um número finito de domínios, passíveis de serem descritos por uma classificação exaustiva. Referindo-se aos Araweté, Viveiros de Castro argumenta, diferentemente: 
A noção jurídica de "propriedade" [...] é o aspecto menos importante, e nem sempre presente, no uso do termo. Os Araweté não parecem conceber de modo geral o cosmos como consistindo em um conjunto de domínios (e seus seres) justapostos, possuídos por diferentes ñã [donos] com quem o homem precisa se entender ou lutar (1986:233).

Embora o cosmos araweté seja povoado por dezenas de espíritos-donos, ferozes e canibais, os humanos não têm que negociar continuamente com eles para realizar suas atividades. A relação que os obseda é aquela entre vivos e mortos ou, mais exatamente, entre vivos e divindades por meio dos mortos. Os Parakanã também não se preocupam em negociar qualquer ato predatório ou apropriador, pois sequer postulam a existência de mestres de animais ou de plantas, não se incorrendo, assim, em qualquer risco ao predá-los. Vários povos, porém, não apenas concebem o mundo como feito de múltiplos domínios, como também se inquietam com o fato de que, para viver, os humanos não podem respeitar seus limites: para plantar, caçar, pescar é preciso adentrar nos espaços alheios, quase sempre com intenções predatórias. Os Miraña do rio Caquetá, por exemplo, concebem a floresta como domínio dos mestres dos animais que "aí reinam do mesmo modo que os mestres de maloca humanos reinam sobre sua gente" (Karadimas 2005:342). As intrusões nesse espaço "são percebidas como atos belicosos contra os animais, conduzidos de modo idêntico às expedições guerreiras do passado" (2005:344).

Mesmo a produção de certos artefatos representa um perigo pois requer, como sugere Guss, uma "transferência de propriedade [ownership]" (1989:61), transferência esta que o autor conceitualiza como uma "conversão de objetos selvagens em objetos domésticos" (:95). Assim, para que os homens yekuana possam cortar as canas com que fazem seus famosos cestos platiformes bicolores, devem solicitar a um xamã que negocie com Yododai - o mestre que planta as canas e as guarda zelosamente. Obtida a permissão, é preciso respeitar uma série de regras durante o corte e o fabrico da cestaria, tempo ao longo do qual emergirá um padrão gráfico associado a Odosha, figura prototípica da predação (1989:106-7;130-2). A conversão-domesticação de que fala Guss é, pois, também a fabricação de um artefato-jaguar.

Em suma, tudo em princípio tem ou pode ter um dono: a floresta, os animais, os rios e as lagoas, mas também uma espécie animal, outra espécie vegetal, ou ainda aquele bambuzal, aquela curva de rio, determinada árvore, uma montanha particular. ${ }^{14}$ Afirmar que o cosmos atual está estruturado por relações de domínio não significa, porém, concebê-lo como organizado exaustivamente em espaços discretos (territórios e jurisdições), como se re- 
sultasse de uma série de enclosure acts decretados ao final do tempo mítico. A passagem do contínuo ao discreto, que a mitologia ameríndia se propõe a contar, implica a constituição de um mundo atravessado por relações de domínio, mas não uma cartografia cósmica de propriedades distintas e exclusivas. Essas relações de domínio são múltiplas e potencialmente infinitas. Tampouco estão dadas de uma vez por todas: elas têm sua dinâmica pósmítica, sendo possível apropriar-se ou ser apropriado, inserindo-se em uma nova relação de domínio. Objetos são fabricados, crianças são engendradas, capacidades são adquiridas, animais são capturados, inimigos são mortos, espíritos são familiarizados, coletivos humanos são conquistados.

Esses processos operam tanto no plano das macrorrelações entre coletivos, como na microprodução da pessoa, que se constitui e se desconstitui continuamente ao apropriar outros e ao ser apropriada por outros. Essa pessoa não é, pois, um self unitário, idêntico a si mesmo. Dizer, porém, que ela é uma pessoa "distribuída" ou "relacional" é insuficiente. A teoria da identidade pessoal de Locke não funda exatamente um indivíduo enclausurado em si mesmo em contraposição à pessoa relacional amazônica, melanésia ou de-nãosei-onde. Como aponta Balibar, Locke toma a identidade como uma relação, o que implica dizer "que ela pressupõe a diferença, ou que ela é [...] um certo modo de tratar a diferença [...] em reduzindo-a a zero" (1998:247). ${ }^{15}$ Também não falta a Locke um modelo de pessoa distribuída (Gell 1998), pois os objetospropriedade são índices de capacidades agentivas. O proprietário lockiano é uma pessoa magnificada, na medida em que, graças a uma relação consigo mesmo, apropria-se do mundo. O próprio (garantido pela consciência de si) e a propriedade (baseada no domínio sobre o corpo) fundam a apropriação, que magnifica a pessoa pela "anexação de" e a "extensão a" coisas.

A distinção crucial quanto ao caso ameríndio decorre, assim, do fato de a relação fundante não ser a identidade consigo mesmo: o Si e o Mesmo não se confundem na construção da pessoa ameríndia. ${ }^{16}$ Daí porque falar em propriedade seja talvez pouco apropriado, pois o próprio ao dono é ser alterado. O caráter múltiplo e fractal das relações de domínio requer pessoas internamente compósitas, "diferentes de si mesmas" (Viveiros de Castro 2002b:377). O modelo do agente não é, assim, o do proprietário que anexa coisas a um Si imutável, mas o do mestre que contém múltiplas singularidades. Desta forma, se os dois modelos, lockiano e ameríndio, são apropriativos, o risco do primeiro é, como diria Kant, a "sociabilidade a-social" do individualismo possessivo, enquanto o risco do segundo é a sociabilidade canibal da singularidade possessiva. Os mecanismos de limitação da apropriação também diferem: de um lado, a responsabilidade moral da pessoa forênsica; do outro, a socialidade do parentesco da pessoa (en)corporada. 


\section{Magnificação e poder}

Assim como o espectro da propriedade privada bloqueou nossa imaginação conceitual sobre as relações de maestria-domínio, também nossa capacidade de pensar o poder nas terras baixas da América do Sul foi obnubilada pelo modelo estatal e pelo foco na coerção. É mister diminuir o fosso criado por certas imagens polares, já seculares, verdadeiros buracos negros que sugam nosso imaginário sempre que se trata de pensar o poder no mundo indígena. É como se tivéssemos que escolher entre um modelo anti-estatal (obsedado negativamente pelo Estado) e um modelo de centralização teleológico (obsedado positivamente pelo Estado). Há que se construir uma nova linguagem, etnograficamente informada, para conceitualizar as relações assimétricas na região sem, de um lado, dissolvê-las em um banho simetrizador ou, de outro, transformá-las em sementes contendo um aparelho estatal em miniatura (um estatúnculo ao qual corresponderia uma estatogênese).

Sugiro que esta linguagem seja a da maestria, enquanto mecanismo de produção de pessoas magnificadas, que contém tanto os dispositivos de produção da potência, como os de solapamento do poder. Parece-me importante localizar na microanálise dessa relação os dispositivos de constituição e desconstituição de relações que implicam controle. Este é um passo crucial para escapar à linguagem essencialista de Clastres, repleta de seres-para e seres-contra e, em particular, de sua metafísica da sociedade primitiva qua absoluto. ${ }^{17}$

O termo "controle" presta-se a confusões. Poderíamos abandoná-lo em definitivo em face das não poucas críticas que sua aplicação a contextos extraocidentais tem recebido. Controle, como se sabe, provém do latim medieval contrarotulus (i.e., uma contra-rol, um registro em duplicata), e tem hoje os traços semânticos de "fiscalizar", "restringir", "exercer domínio". Dispositivos de controle são uma obsessão de nossa engenharia mecânica, psíquica e social: a relação com as máquinas, ou a relação da pessoa consigo mesma, ou a de coletivos com suas partes é eivada por um imperativo de controle. A maestria-domínio indígena não exige esse mesmo imaginário normativo do controle social que, por sua vez, supõe a noção complementar de desvio. Não que faltem princípios de adequação comportamental ou de restrição à ação pessoal nas sociedades indígenas. É mister, porém, não confundi-los com nosso modelo do controle, justamente para que não cometamos o erro inverso: o de abstermo-nos de pensar como as pessoas têm efeitos umas sobre as outras.

Até onde sei, Strathern foi a primeira a elaborar a crítica da noção de controle em associação com o conceito anglo-americano de propriedade: 
“essa noção de controle implica algo como um exercício de propriedade, seja sobre os atributos 'pertencentes' a alguém ou sobre atributos 'pertencentes' a outros e cedidos por eles. O conceito já prejulga a maneira pela qual pessoas impingem-se umas às outras" (1988:141). Trata-se, pois, de não prejulgar, mas sim de investigar, em cada contexto, como pessoas impingem-se umas às outras. O verbo impingir significa "ir contra", "impor", cujo particípio é "impacto". Devemos então perguntar: qual é, afinal, o impacto dos mestres?

Se a definição clássica weberiana de poder como "possibilidade de impor a sua própria vontade, no interior de uma relação social, ainda que contra toda resistência..." (Weber 1984:43) não se aplica bem ao contexto ameríndio, isso se deve menos ao uso do verbo "impor" do que à noção de "própria vontade". Pois justamente xamãs e guerreiros se constituem enquanto tais por integrarem a si relações com outros-sujeitos dotados de vontades-outras, cabendo-lhes impor sua perspectiva, mas sob o constante risco de perdê-la. A potência do mestre é a capacidade de extrair uma ação do xerimbabo. Esta é a coerção, como diria Strathern (1988:272). Mas há uma ambivalência aqui, pois não se sabe exatamente quem causa a ação e quem está agindo. Quem é o agente do canto moropihã do guerreiro araweté, o matador ou sua vítima? Quem é o curador parakanã, o sonhador ou os inimigos oníricos?

Esse caráter paradoxal, em que elementos antagônicos condensam-se na forma de uma imagem ao mesmo tempo singular e múltipla, é a fonte mesma, como propõe Severi (2007), da eficácia ritual desses personagens. Porém, na Amazônia, tal eficácia está eivada de uma instabilidade constitutiva, pois não se sabe jamais quem adotou quem, quem controla quem: para serem potentes, xamãs e guerreiros devem assegurar a condição subjetiva e a capacidade de ação de seus xerimbabos, o que significa que eles não devem jamais se tornar inteiramente mansos e domésticos (Fausto 1999a:949). Daí a ambivalência das figuras do xamã e a do guerreiro na região, sempre em vias de adotar a perspectiva dos outros que contêm em si mesmos.

Ao dispositivo alterante da maestria (o fato de o mestre ser necessariamente afetado por seu xerimbabo) soma-se a pluralidade das relações internas às pessoas magnificadas, o que produz a sua dispersão relacional. Como afirma Rodgers, "o xamã é um ser múltiplo, uma micropopulação de agências xamânicas abrigada em um corpo: portanto, nem suas 'intenções' são jamais exclusivamente 'suas', nem ele está nunca certo de suas próprias intenções" (2002:121). Essa pluralidade também caracteriza o homicida, que contém relações com diferentes espécies de humanos (suas vítimas), mas também com não-humanos, uma vez que a potência predatória deve ser fa- 
bricada antes do ato homicida por meio da jaguarização do futuro matador. Assim, por exemplo, entre os Jívaro, o sucesso na guerra depende do encontro prévio com o arutam, imagem de um ancestral com afecção jaguar, que "vai se alojar no destinatário como um duplo interno" (Taylor 2003:237). ${ }^{18}$

O fato de o caráter plural e alterante da maestria produzir uma instabilidade na relação de domínio ajuda-nos a entender por que, na Amazônia, foi infreqüente a cristalização de um lugar institucional de poder. A própria constituição dessas funções conteria os dispositivos que as solapam, uma vez que a potência depende de uma relação incerta com sujeitos-outros, jamais inteiramente fiéis. Seria incorreto ignorar, porém, que houve (e ainda há) formas institucionalizadas de chefia na região. A questão, portanto, reside em saber como é possível contra-arrestar as tendências centrífugas da relação de maestria-domínio, fazendo delas um mecanismo de concentração e localização do poder.

Minha intuição é a de que isto ocorreu ali onde houve limitação às lógicas multiplicatórias e alterantes da guerra e do xamanismo. Como argumentei alhures, a guerra indígena caracteriza-se por uma ampliação quase irrestrita do número de matadores e de atributos vitais que os guerreiros são capazes de obter e transmitir (Fausto 2001a:305-306, 330-331; Fausto 1999b:272-275). Essa ampliação vincula-se à baixa hierarquização dos homens em função do mérito bélico, pois se trata antes de multiplicar as capacidades regenerativas a serem apropriadas do que ranquear os homens em função de seu poder predatório. É significativo que onde se encontre maior cristalização do poder se encontrem também restrições a essa lógica. Este é o caso, por exemplo, dos povos do Chaco, nos quais a condição de membro do estamento guerreiro era limitada àqueles que efetivamente escalpelassem um inimigo e trouxessem o troféu. É certo que se podia ceder a vítima a um companheiro para que acedesse a tal estatuto, mas a cada troféu correspondia um e apenas um guerreiro (Clastres 1982:222; Sterpin 1993). Já no caso dos Azteca, com estamentos bem mais rígidos, ceder um cativo sacrificial para outra pessoa era crime punido com a morte (Clendinnen 1991:116).

Estes são exemplos de como um mecanismo de dispersão pode se converter em um mecanismo de concentração. É possível que processos semelhantes tenham ocorrido na passagem de sistemas xamânicos àqueles de tipo templo-sacerdote, passagem na qual o surgimento de um xamanismo vertical associado à ancestralidade constituiria um caminho intermédio (Hugh-Jones 1994; Viveiros de Castro 2002c:471-2). As territorializações espacial (o templo) e temporal (a ancestralidade) corresponderiam à conversão de relações múltiplas de domínio em um sistema piramidal e centrípeto de dominação. Esta hipótese talvez nos ajude a conceitualizar a existência pretérita nas 
Américas de megamáquinas predatórias, teocracias estatais que conservaram o princípio canibal como elemento constitutivo do poder, subsumindo a ancestralidade e a predação a uma única estrutura hierárquica.

Seja como for, estamos no terreno das hipóteses, e é melhor voltar logo ao solo firme da etnologia. Retorno pela categoria kanamari -warah, que Costa (2007) traduz por dono-corpo-chefe. Como vimos, ela serve à expressão de uma mesma estrutura em diferentes escalas: almas contidas em corpos, corpos contidos em chefes e chefes contidos em outros chefes. Qual seria o limite desta magnificação? A mitologia kanamari flerta com a imagem de um jaguar universal, corpo global contendo todas as diferenças virtuais que se atualizariam no mundo pós-mítico. Concretamente, o limite era o principal afluente da região, o Juruá, concebido ele mesmo como um -warah, ao qual não correspondia qualquer forma de chefia kanamari. ${ }^{19}$ O lugar estrutural, contudo, estava lá, esperando para ser ocupado por um outro -warah. À maneira do célebre diagrama lévi-straussiano em Histoire de lynx, a estrutura kanamari prevê um lugar para outros donos — ou ainda, para donos-outros, já que esse lugar foi ocupado pelos brancos, assim como ocorreu em outras partes da Amazônia.

\section{Os mestres na história}

A relação de maestria serviu à conceitualização das assimetrias que marcaram a história colonial e pós-colonial. Esse foi um fato recorrente, que reapareceu, aqui e ali, na interação com missionários, com as tropas de resgate, com os patrões da borracha ou, mais recentemente, com os funcionários leigos dos estados nacionais. Esse esquema relacional serviu como dobradiça na articulação do sistema de cativos provenientes da guerra indígena e o sistema escravista colonial (Karadimas 2001; Santos-Granero 2005), assim como serviria posteriormente à economia do aviamento durante o ciclo da borracha. Funcionou como articulador de um sistema voltado para a extração de capacidades regenerativas de pessoas para outro de extração de sobretrabalho e produção de bens. A estrutura hierárquica da maestria, com sua dupla face (predação e proteção), serviu ainda na articulação com as estruturas de poder colonial, em especial, no contexto dos aldeamentos e, posteriormente, do regime tutelar (Machado 1994).

Há vários exemplos etnográficos da equiparação dos brancos a donosmestres. Explorei este ponto ao descrever como os Parakanã Ocidentais assimilaram-nos aos poderosos inimigos oníricos, que são concebidos como xerimbabos do sonhador, pois curam e doam cantos sem nada pedir em troca. 
Mostrei ainda que havia uma curiosa inversão dessa relação, evidenciada pelo uso do vocativo: o sonhador dirige-se aos inimigos como wetom, "meu pai", ou mais freqüentemente como miangá, um termo formal que se aplica a "pais" (mas jamais ao próprio pai). ${ }^{20}$ Foi justamente este o termo que os Parakanã Ocidentais utilizaram nas suas relações com os brancos durante boa parte do século XX, contrastando com os termos de afinidade com que se dirigiam aos inimigos indígenas. O uso remonta ao final do século XIX, quando afirmaram ter aprendido como extrair mercadorias dos brancos de modo pacífico, e se reforçou durante o longo processo de "pacificação" iniciado no final dos anos 1920. Da perspectiva dos Parakanã, os agentes do Estado portavam-se como verdadeiros pais-doadores sujeitos ao controle indígena (Fausto 2001a:469-531, 2002b, 2002c). É esta justamente a magia do sonhador parakanã: sua potência xamânica (ipajé) corresponde à capacidade de extrair uma ação voluntária dos inimigos oníricos; magia semelhante, aliás, àquela das artes decorativas, segundo Gell (1998), cujo encantamento visaria enredar o recipiente, fazendo-o, no caso do parceiro do kula, ceder os seus mais preciosos objetos.

Há outros contextos amazônicos nos quais a maestria também se aplicou à relação com os brancos. É o caso dos Paumari, um povo de língua arawá, para os quais, segundo Bonilla (2007), todos os existentes (animais, plantas, objetos) possuem uma forma humana, concebida como um dono-mestre. A relação do dono com sua espécie é pensada ao modo da familiarização de animais e da filiação adotiva, como ocorre em tantos outros exemplos amazônicos. Mas há também relações assimétricas entre diferentes espécies, que são assimiladas à relação patrão-empregado (Bonilla 2007:199-205). Os brancos representam bem essa dupla condição de "mestres" e "patrões", a tal ponto que os Paumari tomaram emprestado um termo da Língua Geral Amazônica para designar os brancos em geral: Jara (i.e., "dono").

Os brancos são mestres, portanto, dotados de potência predatória, que se expressa na captura de crianças paumari, conservadas em caixas como animais de estimação. Os xamãs devem libertar essas crianças, assim como o fazem em outros casos de "roubo da alma" (Bonilla 2007:87). Se os brancos aparecem como mais uma figura dentre os mestres que povoam o mundo não-humano, não é apenas o modelo indígena que se projeta sobre a relação com os colonizadores; o próprio modelo é infletido pela relação histórica de trabalho e dependência. Nas palavras de um ex-xamã paumari: "O xamã é o pai do itavari [espírito auxiliar]. É como um governador. Aquilo que o xamã lhe disser, ele deverá fazer e obedecer, como um empregado. Os itavari têm muita vontade de trabalhar e de estar sob as ordens do xamã, pois assim eles podem vir ao ihinika [ritual]" (Bonilla 2007:355). 
Como argumenta Bonilla, há ainda uma outra volta nesse parafuso, pois o modelo da adoção, infletido pela relação patrão-empregado, foi um modo de atuar na interação assimétrica com os brancos, de forma a tentar controlar seu potencial predatório. Os Paumari colocaram-se a si mesmos na posição de xerimbabos, buscando converter uma relação predatória em cuidado e proteção. A estratégia de submissão contém também um reclamo, pois é um modo de extrair a ação correspondente à posição de dono, definido como aquele que cuida de e alimenta seus filhos-xerimbabos (Bonilla 2005:58). ${ }^{21}$ Os mestres vivem em um regime de abundância — são maiores, mais ricos, mais férteis - e espera-se que, não se comportando como predadores, comportem-se como provedores.

A mesma ressonância entre relações históricas de poder e exploração e a cosmologia indígena encontra-se entre os Ávila Runa do Equador (Kohn 2002, 2007). Aí os mestres dos animais expressam diferentes figuras de poder e autoridade do passado pré-colonial, colonial e pós-colonial. O mundo em que vivem é descrito como uma rede urbana com sua própria hierarquia: os principais donos, curagas, moram em uma espécie de "Quito na Floresta", localizada dentro do Vulcão Sumaco, articulada por estradas a outras cidades menores onde vivem donos menos importantes. Outra imagem mobilizada para descrever esse mundo é a das haciendas com seus patrões-proprietários e seus animais domésticos encerrados em currais. ${ }^{22}$ Ambos, cidades e haciendas, são concebidos como lugares de abundância, nos quais os mestres mais poderosos circulam com jaguares à maneira de cães de estimação (Kohn 2007:109-120). ${ }^{23}$

A relação de maestria-domínio não é produtiva apenas para se pensarem as assimetrias entre índios e brancos ou humanos e não-humanos. Ela é também relevante para a análise das relações assimétricas entre povos indígenas. Sugiro que tenha sido um dispositivo sociológico bastante importante no passado, servindo à estruturação de relações hierárquicas entre diferentes grupos indígenas, algo que ainda se pode observar hoje em alguns sistemas regionais. Este parece ser o caso da relação assimétrica dos Maku com os Tukano e os Arawak no Alto Rio Negro (Ramos, Silverwood-Cope \& Oliveira 1980), ou aquela dos Guaná (Terena e Kinikinau) com os Mbayá-Guaykuru (Kadiwéu), cujas evidências históricas remontam à viagem de Ulrich Schmidel, na primeira metade do século XVI (Cardoso de Oliveira 1976:31-2). ${ }^{24}$

São da mesma época as primeiras informações sobre os Chiriguano, um povo formado pela fusão assimétrica e violenta entre Guarani e Chané, estes últimos falantes de uma língua arawak (Combès \& Saignes 1991). No século XVI, os Chané foram literalmente canibalizados e incorporados em uma posição de subordinação, a ponto de serem definidos como "escravos" (tapii) em relação aos Guarani, vistos como "mestres" (iya) (Combès \& Lowrey 
2006:692). ${ }^{25}$ Contudo, a partir do século XIX, um grupo de descendência chané, os Izoceños, começou a buscar reverter a assimetria, proclamando-se, significativamente, Iyambae: "os sem dono". O termo utilizado inicialmente como sobrenome por uma dinastia de chefes izoceños, converteu-se hoje em um novo marcador étnico, ao qual corresponde um território denominado "terra sem dono" (Ivi Iyambae) e uma fundação homônima (Combès \& Villar 2004). No mercado das ONGs, produziu-se uma curiosa ressonância:

Para os estranhos, a Izozog [o nome] sugere liberdade e igualdade, podendo evocar o cenário da "Sociedade contra o Estado" que Pierre Clastres (1982 [1974]), com base em exemplos guarani, incluiu na expressão. Para os Izoceños, ao contrário, ele se refere a uma casta dirigente. Em Izozog, ser "sem dono" é ocupar uma posição social particular, materialmente compensatória; ser "sem mestre" é ocupar o topo de uma hierarquia arawak (Combès \& Lowrey 2006:700-701).

Não me cabe aqui abordar a qualidade dessa hierarquia, nem discutir sua associação com os povos arawak (ver Heckenberger 2002, Santos-Granero 2002). Tampouco me cabe perguntar se, quando, onde e como relações de domínio converteram-se em relações de dominação. Para fins deste texto, basta notar a produtividade e a generalidade do idioma do dono-mestre.

\section{Conclusão}

Vimos como a relação de maestria, concebida como uma filiação adotiva, opera em diferentes escalas, desde a microconstituição da pessoa até a macroconstituição do cosmos. Vimos igualmente que é um esquema relacional que define interações nas mais diversas esferas, bem como entre as mais diversas entidades (humanos, animais, plantas, espíritos, artefatos).$^{26}$ Vimos, finalmente, que há uma dinâmica na qual esse mesmo esquema é infletido por situações históricas, tornando-se um modelo para pensar e agir em novas circunstâncias. Afinal, o que estou buscando sugerir?

O primeiro parágrafo deste texto já deveria ter esclarecido minhas intenções, pois se trata da paráfrase de uma passagem de Lévi-Strauss (1943), contida em um artigo que inaugurou toda uma sofisticada reflexão americanista sobre the brother-in-law relationship, da qual somos tributários graças aos trabalhos de vários colegas. ${ }^{27} \mathrm{O}$ que estou sugerindo, enfim, é que a relação de maestria opera, à maneira da afinidade simétrica, como um "operador cosmológico" (Viveiros de Castro 1993). Se temos, como propõe 
Viveiros de Castro, uma afinidade sem afins - intensiva e potencial temos também um tipo de filiação cosmopolítica e interespecífica (uma metafiliação), na qual a adoção, e não a transmissão vertical de substâncias, é o elemento crucial..$^{28}$ Mas não se poderia dizer o mesmo de outras modalidades relacionais, tais como a afinidade assimétrica (a relação sogro-genro) ou a consangüinidade simétrica (a germanidade)? Na minha percepção elas não possuem, senão em contextos específicos, o nível de generalidade do cunhadio e da filiação adotiva. Isto porque ocupam as posições polares da identidade e da diferença, tendendo a deslizar, de um lado, para a fixidez estéril do mesmo e, de outro, para a potência canibal incontrolável.

Na Amazônia, a germanidade, em particular de mesmo sexo, é comumente tida como o âmago mais coeso da identidade, como o núcleo duro do parentesco (Fausto 1991:72), não se estendendo para além desse domínio. Não temos uma metagermanidade como ocorre no caso indiano, ou uma fraternidade universal à maneira cristã. Na Amazônia, a germanidade só articula domínios mais amplos ali onde houve conversões religiosas, em especial ao novo evangelismo (Vilaça 1996). Sempre que a germanidade surge como idioma sociocósmico, introduz-se uma assimetria baseada na ordem dos nascimentos. ${ }^{29}$ Este é o caso das conhecidas sagas gemelares, como mostrou Lévi-Strauss (1991), mas também dos mitos sobre a origem da diferença entre índios e brancos, equiparados a uma inversão de senioridade entre irmãos de sexo masculino. ${ }^{30} \mathrm{~A}$ ordem dos nascimentos pode servir ainda como régua sociocósmica para marcar diferenças hierárquicas entre segmentos de um mesmo povo, como ocorre no sistema do Alto Rio Negro, ou entre germanos com ascendência de chefia, como se dá no Alto Xingu. Enquanto relação identitária, porém, a germanidade não constitui um idioma cosmopolítico generalizado, ainda que o grupo de germanos seja uma unidade fundamental na estruturação das dinâmicas políticas na região.

A relação sogro-genro encontra-se no pólo oposto ao da germanidade, pois se compõe de diferenças e assimetrias sobrepostas: sobre uma base de afinidade, erguem-se duas outras assimetrias, aquela entre tomador-doador de mulheres e aquela entre gerações. A relação é potente demais, logo deslizando para figuras de poder e para a voracidade canibal. Não é à toa que as duas imagens proeminentes dessa relação sejam a do genro trabalhador e a do sogro-jaguar, como sugerem, por exemplo, os mitos yekuana, em que o genro tem que realizar tarefas sobre-humanas para não ser devorado por seu sogro canibal (Guss 1989:80, 94).

Como mostram Turner $(1979,1991)$ e Rivière $(1984,1987)$, esta é a única relação na Amazônia que envolve substituição do trabalho de alguém por outrem. O genro trabalha para ou no lugar do sogro: ele deve caçar, pescar, abrir 
roça, construir a casa. Essa obrigação deriva do próprio fato do casamento e não há muitas formas de se evadir dela inteiramente, a não ser nos casamentos por captura. Mesmo no Alto Xingu, onde há em certas situações pagamento-danoiva, este serve apenas para atenuar, não para cancelar, os serviços prestados ao sogro. Rivière e Turner identificam nessa relação um mecanismo de controle de pessoas com reflexos sobre a formação de lideranças e, de maneira geral, sobre a autonomia de homens adultos. Há variações importantes em seus efeitos estruturais conforme a sociedade seja uxorilocal ou virilocal, a regra de residência seja mecânica ou estatística, o serviço-da-noiva seja mais ou menos longo. Ainda assim, é provável que se tivessem que escolher alguma relação de parentesco envolvendo autoridade e controle na Amazônia indígena, nove entre dez especialistas apontariam a relação entre sogro e genro. ${ }^{31}$

Não obstante, ela não fornece um idioma geral para esquematizar relações tão diversas como aquelas entre xamãs e espíritos familiares, guerreiros e vítimas, captores e cativos, mestres e espécies, mesmo sabendo-se que, na Amazônia, a posição do genro em regime uxorilocal é freqüentemente comparada a de um cativo ou a de um animal de estimação. A menor generalidade da afinidade assimétrica deve-se ao fato de os mestres amazônicos caracterizarem-se por sua dupla-face: são jaguares vorazes para os outros e pais protetores para os membros de seu coletivo. Sogros, ao contrário, tendem a ter uma face só, sendo demasiadamente jaguares. Isto não significa que a relação não possa, em certos contextos, operar como idioma cosmopolítico. Os povos tupi, em sua inclinação canibal, sempre flertaram com essa possibilidade. Entre os Araweté, por exemplo, a relação esquematiza aquela entre vivos e divindades, sendo atravessada pela mesma ambivalência posicional de outras relações xamânicas (Viveiros de Castro 1992:218).

Por fim, resta-nos incorporar a diferença de sexo, até aqui não considerada no argumento. Há duas relações cross-sex que parecem articular domínios sociocósmicos distintos: a maternidade e a matrimonialidade. A maternidade é um caso particular da relação de maestria, na qual se põe em relevo a função-genitor do dono. Ela se expressa nas figuras da mãe da caça (ou de alguma espécie em particular) ou da mãe de plantas (em especial, as alucinógenas). Contudo, o uso da categoria "mãe" para designar entidades similares aos donos é restrita etnograficamente, além de não se aplicar ao espectro mais geral de relações de domínio que caracterizam a noção de dono-mestre. ${ }^{32}$

Já a matrimonialidade tem outro estatuto, em especial na mitologia, na qual aparece como um mecanismo crucial de passagem de uma situação de parentesco a outra. Os casamentos intra-específicos são numerosos nos mitos e, muitas vezes, têm maior destaque que as relações de afinidade que neces- 
sariamente implicam. Alguns povos indígenas, ademais, concebem a relação do xamã com os espíritos auxiliares como um vínculo matrimonial. Os exemplos que conheço se concentram na Amazônia Ocidental, ocorrendo entre os Shipibo-Conibo do Peru (D'Anglure \& Morin 1998), os Chimanes da Bolívia (Daillant 1998, 2003:308-313), os Achuar do Ecuador (Descola 1986:346-48; Taylor 1993:437-439), os Harakmbut do Peru (Califano 1988:117-119), os Wari' de Rondônia (Vilaça 2006:202-203) e os os Nambikwara-Mamaindê do Mato Grosso, ambos no Brasil (Miller 2007:198-200).

A matrimonialidade expressa de modo dinâmico um conjunto de relações de parentesco, pois o xamã constitui verdadeiras famílias espirituais: tem uma esposa, afins e gera filhos-espíritos. No entanto, parece haver aqui, de um lado, uma ênfase na paternidade - um homem começa sua vida xamânica como marido e termina como pai, vínculo tido como mais estável e seguro (D'Anglure \& Morin 1998:67; Daillant 2003:313); de outro, uma relativa desmarcação da afinidade. ${ }^{33}$ É como se a própria matrimonialidade convergisse para a adoção e não para a aliança, à diferença do que ocorre, segundo Hamayon (1990), no xamanismo de caça siberiano.

Os Nambikwara-Mamaindê nos fornecem o exemplo mais sugestivo dessa assimilação entre casamento e familiarização (Fausto 2001b). A esposa-espírito, que é um jaguar, é denominada da mãindu ("minha criação" ou "meu xerimbabo") pelo marido-xamã. Como era de se esperar, observa-se também aqui a instabilidade posicional que marca, em geral, as relações de mútua constituição entre xamãs e auxiliares: "não se sabe ao certo quem está 'criando' quem. Embora o xamã chame a mulher-espírito de 'minha criação', ao partilhar comida e enfeites corporais com ela o xamã indica que é ele quem está sendo 'criado' por ela" (Miller 2007:199).

Em resumo, nenhuma das relações analisadas acima parece ter, na Amazônia, a mesma generalidade que a afinidade simétrica e a consangüinidade assimétrica. A primeira combina diferença e simetria; a segunda, identidade e assimetria. A sobreposição de novas diferenças (de gênero ou geração) não se mostra tão operativa e é restrita tanto em termos de distribuição étnica e espacial, como de domínios sociocósmicos. O metacunhadio e a metafiliação são ambos eletivos, dispensando qualquer outra relação prévia: pode se ser inimigo-cunhado de quem quer que seja, assim como pode se adotar o inimigo que se queira. Não estamos falando, porém, de qualquer filiação adotiva, assim como não falamos de qualquer cunhadio. Este último, em sua modalidade intensiva (a afinidade potencial), é uma figura da inimizade, e o primeiro é uma figura do domínio, da relação assimétrica entre o dono-mestre (que pode ser também um pai, um chefe ou mesmo um patrão) e seus filhos-xerimbabos. 
Há um último ponto que gostaria de marcar: a adoção é, por assim dizer, uma filiação incompleta. Ela não produz uma identidade plena, senão uma relação ambivalente, em que o substrato da inimizade é obviado, mas não inteiramente neutralizado. Daí a minha insistência na permanência da perspectiva do outro no caso da relação xamã-auxiliares ou matador-vítima; daí também por que cativos de guerra e animais familiares freqüentemente recebem um tratamento oscilante entre o cuidado e a crueldade. À duplaface do mestre corresponde a face-dupla do xerimbabo: ele é um outro e jamais deixará de sê-lo completamente.

Para encerrar, permito-me parafrasear uma vez mais Claude LéviStrauss, afirmando que um número suficiente de indicações convergentes foi registrado, de tal sorte que podemos considerar a relação de maestria um traço característico da sociocosmologia amazônica, configurando um mundo de donos e inimigos, mas não necessariamente de dominação e domínio privado. 


\section{Notas}

* Há muitos anos venho escrevendo mentalmente este texto. Apresentei algumas dessas idéias em meus cursos no PPGAS-Museu Nacional, assim como em um seminário de Carlo Severi na EHESS, em 2005, a quem agradeço o convite. Agradeço a Marina Velasco e Federico Neiburg a oportunidade de aprendermos juntos Locke em um curso a seis mãos que ministramos em 2004. Agradeço ainda a Marc Brightman, Vanessa Grotti e Olga Ulturgasheva pelo convite para participar da conferência "Humains, animaux, plantes et choses: la notion de personne en Amazonie et Sibérie contemporaines", no Musée du Quai Branly, em junho de 2008, onde apresentei este texto. Finalmente, agradeço a leitura e/ou comentários de Aparecida Vilaça, Cesar Gordon, Federico Neiburg, Joana Miller, Jose Antonio Kelly, Marina Velasco, Marnio Teixeira-Pinto, Oiara Bonilla, Stephen Hugh-Jones e, particularmente, de Luiz Costa, com quem mantenho um diálogo intenso sobre o tema desde que os Kanamari imaginaram fazer dele um novo -warah. As traduções de todas as citações são de minha responsabilidade.

${ }^{1}$ O yawalapiti é uma língua arawak meridional. Os cognatos de wököti na região são o wekehe mehinaku (Gregor 1977) e o wekehö wauja (Barcelos Neto 2004). Para uma discussão sofisticada sobre donos e propriedade entre os arawak do Alto Xingu, ver Ball (2007).

${ }^{3}$ A sinonímia corpo e dono é incomum. Até onde sei, encontra-se também entre os Bakairi (Collet 2006:150-154) e os Chimane (Daillant com. pessoal). Para uma interessante discussão sobre a noção bakairi de dono (sodo) como mediador entre indivíduos e coletividades, ver Collet (2006:153).

${ }^{3}$ Emprego o conceito de singularidade para designar uma entidade internamente múltipla e não-idêntica a si mesma, acompanhando o seu uso contemporâneo, inspirado em Deleuze (1968). Por vezes, emprego também a expressão compósita "singularidade plural". Na antropologia, o conceito tem ressonâncias, como apontou Viveiros de Castro (2007), com as propostas de Strathern $(1988,1992)$ e Wagner (1991) de redefinir a relação entre parte/todo, particular/coletivo em diferentes escalas, desde a microconstituição da pessoa até a macroconstituição do social. Embora não possa desenvolver a reflexão aqui, é importante notar que o tipo de soberania implicado pela noção amazônica de "dono" é diferente daquele implicado por nosso conceito de corpo político; ou seja, o chefe-dono-corpo não é um Leviatã.

${ }^{4}$ Ver Fausto (2001a), bem como os artigos de Erikson $(1987,2000)$ e Descola (1994), nos quais me inspirei. No que toca ao xamanismo, ver Albert para os Yanomami (1985:316), Bonilla para os Paumari (2007:355), Briggs para os Warao (1994:141-142), Chaumeil para os Yágua (1983:120), Costa para os Kanamari (2007:49), Henry para os Jê meridionais (1964:73), Wagley para os Tapirapé (1976:242). No que se refere à guerra e aos rituais de troféu, ver Menget para os Ikpeng (1988:67), Santos-Granero para os Conibo (2005:156-157), Sterpin para os Nivakle (1993:42), Taylor para os 
Jívaro (1994). Em relação a objetos cerimoniais, ver Staden sobre maracás tupinambá (1974 [1557]:174), Menget sobre flautas ikpeng (1988), Hugh-Jones sobre adornos corporais e instrumentos musicais barasana (1996:141), bem como Maia Figueiredo (2007) para as flautas jurupari dos Baré.

${ }^{5}$ Neste texto, não terei condições de discutir a qualidade do "cuidado", um tema central em trabalhos de Overing (1999), inspirados na filosofia moral das virtudes (MacIntyre 1981; Larrabee 1993; Baier 1994). Tampouco me deterei no caráter ambivalente - entre o cuidado e o descuido - das relações com órfãos, cativos e xerimbabos na Amazônia.

${ }^{6} \mathrm{O}$ termo iamït aplica-se aos animais controlados pelos mestres, aos xerimbabos criados pelos humanos e aos órfãos adotados (Teixeira-Pinto 1997:314).

${ }^{7}$ Analisando as visões da ayahuasca e a relação feto-placenta entre os Piro, Gow (1999:237) sugere que essa topologia é a de uma garrafa de Klein, na qual o interior é simultaneamente o exterior do recipiente.

${ }^{8}$ A reificação da forma-chefe, que faz dele a imagem singular de um donomestre, também faz dele algo que pertence à comunidade: "Pessoas são possuídas como coisas por meio de uma fabricação político-ritual, que apresenta a pessoa sendo reivindicada por outra como singular, inteira e total [whole]..." (Strathern 2005:120). Inteira e total, mas simultaneamente singular e plural, pois não se opõe aqui o individual ao coletivo: "se o que vemos é um homem ou um clã é irrelevante: a ação coletiva magnifica a performance de cada homem, mas não é diferente em natureza da sua própria magnificação como uma pessoa singular" (Strathern 1999:37).

${ }^{9}$ Como procurei mostrar, essa partição presa/predador é característica da constituição da pessoa na Amazônia (Fausto 2002a, 2007; Taylor 2000). Para uma formulação diferente mas consonante, ver a análise de Gordon (2006:217-218) das categorias xikrin àkrê (caracterizada como capacidade de auto-subjetificação e alter-objetificação) e uabô (caracterizada como capacidade de auto-objetificação e alter-subjetificação).

${ }^{10}$ Mesmo no que se refere a Locke, focalizo apenas o Segundo tratado sobre o governo e o capítulo XXVII, Livro 2, do Ensaio sobre o entendimento humano. Estou ciente de que há, em Locke, um outro modelo da pessoa, caracterizada como repositório passivo de capacidades, que permeia suas idéias sobre a educação, especialmente de trabalhadores fabris (Tully 1993a:88). Tampouco desconheço que a noção de indivíduo como proprietário de si mesmo (portanto, como não-escravo) remete a uma longa tradição do direito romano, que é retomada por Grotius, Hobbes e os Levellers, antes de Locke (Tully 1993b).

${ }^{11}$ Não é de surpreender que o argumento cause estranheza a alguns comentadores. Lloyd Thomas, por exemplo, considera sua premissa absurda, pois se baseia na idéia de que a mistura de secreções corporais com as coisas adiciona a estas algo de que a Natureza não lhes provia: "o trabalho não pode misturar-se às substâncias 
das quais as coisas são feitas" (Lloyd Thomas 1995:109). De uma perspectiva antropológica, ao contrário, o argumento encontra inúmeras ressonâncias etnográficas.

${ }^{12}$ A primeira fratura que dá ensejo à narrativa ocorre entre cunhados assimétricos: o cunhado abandonado é o jovem irmão da esposa, i.e., um homem solteiro ainda vivendo na casa dos pais para a qual se mudou o marido da irmã. Há uma homologia entre o afastamento deste último em relação a sua casa natal e a do jovem cunhado deixado sobre o rochedo.

${ }^{13}$ A expressão foi utilizada para explicar-me por que a antiga escola estava praticamente abandonada, em 1998, ainda que considerassem a educação escolar de extrema importância. Qualquer pesquisador que já tenha tentado dar algo "em comum" a um povo indígena, deve ter se deparado com um impasse, pois tudo tem sempre um dono. Hoje, entre os Kuikuro, com a proliferação de objetos de maior valor marca-se a distinção entre o que é da "comunidade" e o que é "particular", dois termos que são entremeados, em português, a frases em kuikuro. Da "comunidade" são os objetos que pertencem ao chefe sem serem de seu domínio privado.

${ }^{14}$ Digo em princípio, pois há grande variação etnográfica. Se em alguns casos há donos demais, há também animais que podem ser descritos como "donos de si mesmo", tais como o jaguar (Fausto 2007:509), bem como seres que não têm donos, nem são dotados de subjetividade.

${ }^{15}$ Donde conclui Balibar, com certa ironia, que a noção da identidade como aquilo que "difere do diferente" não é uma descoberta da dialética hegeliana.

${ }^{16}$ Conviria precisar essa "especificidade ameríndia", pois há vários outros modelos da identidade pessoal no Ocidente que, ao contrário de Locke, não se baseiam na equação entre ipse (self) e idem (same). Isso vale também para o tema correlato da relação entre identidade e alteridade (ver Descombes 1979). Como afirma Ricoeur "a ipseidade do si-mesmo implica a alteridade em um grau tão íntimo que uma não pode ser pensada sem a outra, que uma passa na outra, como se diria em linguagem hegeliana" (1990:14). Seria importante fundar rigorosamente as diferenças e as semelhanças entre nossas alternativas filosóficas e as cosmologias indígenas, algo que, no entanto, escapa aos objetivos deste texto e à capacidade do seu autor.

${ }^{17}$ Refiro-me, sobretudo, à "Sociedade contra o Estado", em que a sociedade primitiva aparece como uma espécie de sonho gulaguiano: "a propriedade essencial [...] da sociedade primitiva é exercer um poder absoluto e complexo sobre tudo que a compõe, é interditar a autonomia de qualquer um dos subconjuntos que a constituem, é manter todos os movimentos internos, conscientes e inconscientes, que alimentam a vida social, nos limites e na direção desejados pela sociedade [...] Sociedade à qual nada escapa, que nada deixa sair de si, pois todas as saídas estão fechadas. Sociedade que, por conseguinte, deveria eternamente se reproduzir sem que nada de substancial a afetasse através do tempo" (Clastres 1978:147-148).

${ }^{18}$ Já entre os Yanomami, antes da expedição bélica, os guerreiros submetiam-se 
a um ritual para absorver uma imagem-urubu, necessária à digestão da futura vítima (Albert 1985:363), enquanto entre os Wayana, os homens recebiam escarificações com os padrões do jaguar ou de aves de rapina para incutir-lhes as disposições predatórias necessárias (van Velthem 2003:354).

${ }^{19}$ A estrutura kanamari mapeada na hidrografia, em que o maior rio da região é o -warah que contém os seus tributários que, por sua vez, contêm seus próprios afluentes e assim por diante, remete-nos à estrutura hierárquica do sistema da borracha. Sobre a relação entre essa cartografia e o xamanismo, ver Gow (1994) e Carneiro da Cunha (1998).

${ }^{20}$ Nos sonhos, o vocativo aplica-se apenas aos humanos-bestiais, figuras excessivas e monstruosas, mas humanas. Já os jaguares são tratados como sogros, enquanto os outros animais são interpelados como tywa-kwai, um termo com conotações de afinidade simétrica (Fausto 2001a:374).

${ }^{21}$ Essa estratégia, na qual um sujeito busca colocar-se sob a proteção de um mestre e dele extrair uma ação, caracteriza também a linguagem afetiva das relações interpessoais entre os Candoshi, para os quais "o paradigma da familiarização constitui [...] a base conceitual de todas as relações afetivas mantidas no seio da família" (Surrallès 2003:69). Já entre os Toba do Chaco, a linguagem de submissão visa obter a compaixão e provocar a generosidade dos espíritos-mestres (Tola 2006).

${ }^{22}$ Essa mesma imagem aparece entre os Chimanes, para quem o mestre é um proprietário que possui animais de estimação e pessoas a seu serviço. A figura é freqüentemente comparada aos fazendeiros bolivianos com seu gado e seus vaqueiros (Daillant 2003:310, 317).

${ }^{23}$ A associação entre cão e jaguar, inclusive lexical, ocorreu em algumas partes da América e isto não se deve apenas à semelhança morfológica e comportamental (muitos cães dos conquistadores eram caçadores de grande porte), mas se deve também à sua condição de animal feroz domesticado sob o controle de um dono, o que permitiu associá-lo aos jaguares (invisíveis), familiarizados por xamãs e guerreiros.

${ }^{24}$ A relação de dependência e proteção entre esses povos contrasta com a violência dos Guaikuru contra os Guaxi, os Guató e os Chamacoco, indicando que os Guaná tentaram controlar a predação por meio da submissão, assim como o fizeram os Paumari na relação com os brancos.

${ }^{25}$ A tradução de tapii por "escravo" deve ser vista com cuidado (ver Combès 2005:60-68). No Tupi da costa, o termo designava os índios não-tupi, mas não indicava uma relação de submissão, como parece ter ocorrido no caso chiriguano. Para uma retomada do tema da escravidão e de outras formas de subordinação entre povos indígenas, ver Santos-Granero (2005; no prelo).

${ }^{26}$ Seria importante investigar o idioma das relações de simbiose, parasitismo, simultaneidade, partilha ou predação no mundo natural. Minha impressão é que elas 
costumam ser descritas ou pela afinidade ou pelo domínio. Entre os Kuikuro, temos animais que são "primos" de outros, bem como animais que são "donos" de plantas (e.g., o beija-flor e o pequi, certa lagarta e o tabaco).

${ }^{27}$ Ver, sobretudo, a síntese inovadora de Viveiros de Castro (1993), erguida sobre os trabalhos de Rivière (1969, 1984), Overing Kaplan (1975, 1984), Basso (1975), Menget (1977), Carneiro da Cunha (1978), Taylor (1983, 1985, 1989), Albert (1985), Erikson (1986), entre outros. Ver também os trabalhos subseqüentes de Descola (1993, 2001) e Taylor (2000). Para uma discussão sobre o caráter inaugural do artigo de Lévi-Strauss, ver Coelho de Souza e Fausto (2004).

${ }^{28}$ Utilizo o prefixo meta- no sentido que lhe confere Taylor (2000:312) que, por sua vez, o toma da expressão de Jamous (1991) sobre a metagermanidade na Índia (ver também Dumont 1975).

${ }^{29}$ A única exceção que me vem à mente é a relação da pessoa guajá com o seu homônimo (animal, planta, artefato), relação esta que é concebida como de germanidade (Cormier 2003:91).

${ }^{30}$ Ver, por exemplo, o mito barasana analisado por Hugh-Jones (1988:143-44), ou a versão seiscentista tupinambá relatada por Abbeville (1975 [1614]:251-2).

${ }^{31}$ Para uma releitura do tema do controle e da liderança no caso guianês, incorporando uma discussão sobre a noção de propriedade, ver Brightman (2007). Para uma hipótese geral sobre os efeitos estruturais do casamento em sociedades do tipo serviço-da-noiva, ver o célebre artigo de Collier e Rosaldo (1981). Para uma análise crítica dessa hipótese no contexto melanésio, ver Kelly (1993:415-525); no contexto amazônico, ver Fausto (2001a:201-210).

32 Deve-se tomar cuidado com as traduções. Assim, por exemplo, a "mãe do pecari" entre os Munduruku (Murphy 1958), ou as "mães da caça" entre os Achuar (Descola 1986:317) são efetivamente ditas "mãe" na língua indígena. Já a tradução regional do termo hamwo yágua ou wachipai arakambut por "madre" é equívoca, pois tem outro significado nessas línguas (Chaumeil 1983:74; Gray 1997:53).

${ }^{33}$ No caso chimane, Daillant afirma que os xamãs "não conhecem os verdadeiros irmãos de suas esposas" (2003:325). A relação com o sogro também parece ser desmarcada, pois os parentes espirituais do xamã são intercessores junto aos mestres dos animais que, por sua vez, são concebidos como avós dos humanos. No caso nambikwara, afirma-se que, ao se casar com uma mulher-espírito, "o xamã passa a ser acompanhado pelos espíritos dos mortos [...], aos quais ele se refere como 'meus parentes', 'meu pessoal' (da waintãdu)", termo que conota multiplicidade e pode ser traduzido por 'os meus muitos'" (Miller 2007:200). 


\section{Referências bibliográficas}

ABBEVILLE, Claude d'. 1975 [1614]. História da missão dos padres capuchinhos na ilha do Maranhão e terras circunvizinhas. São Paulo: Itatiaia/Edusp.

ALBERT, Bruce. 1985. Temps du sang, temps des cendres: représentation de la maladie, système rituel et espace politique chez les Yanomami du SudEst (Amazonie brésilienne). Thèse de doctorat, Paris, Université de Paris-X (Nanterre).

BAIER, Annette. 1994. Moral prejudices: essays on ethics. Cambridge, Mass.: Harvard University Press.

BALIBAR, Étienne. 1998. "Introduction. Le traité lockien de l'identité" et "Glossaire". In: J. Locke (org.), Identité et différence. L'invention de la conscience. Paris: Points. pp. 9$101 ; 183-261$.

BALL, Christopher G. 2007. Out of the park: trajectories of Wauja (Xingu, arawak) language and culture. $\mathrm{PhD}$ dissertation, University of Chicago.

BARCELOS NETO, Aristóteles. 2004. Apapaatai: rituais de máscaras no Xingu. Tese de doutorado, Departamento de Antropologia, Universidade de São Paulo.

BASSO, Ellen B. 1975. "Kalapalo affinity: its cultural and social contexts". American Ethnologist, 2(2):207-228.

BILHAUT, Anne-Gaël. 2007. Le réveil de L'immateriel: la production onirique du patrimoine des indiens Zápara (Haute Amazonie). Thèse de doctorat, Université Paris X (Nanterre).

BONILLA, Oiara. 2005. "O bom patrão e o inimigo voraz: predação e comércio na cosmologia paumari". Mana: Estudos de Antropologia Social, 11(1):41-66.
2007. Des proies si désirables: soumission et prédation pour le Paumari d'Amazonie brésilienne. Thèse de Doctorat, École des Hauts Études en Sciences Sociales.

BRIGGS, Charles. 1994. "The sting of the ray: bodies, agency, and grammar in Warao curing". Journal of American Folklore, 107(423):139-66.

BRIGHTMAN, Marc. 2007. Amerindian leadership in Guianese Amazonia. Doctoral thesis, Department of Social Anthropology, University of Cambridge.

CALIFANO, Mario. 1988. "El chamanismo huachipaire y zapiteri (Harákmbet: Amazonia Sud Occidental del Perú)". Anthropos, 83(1-3):109-134.

CARDOSO DE OLIVEIRA, Roberto. 1976. Do índio ao bugre: o processo de assimilação dos Terêna. Rio de Janeiro: Livraria F. Alves Editora.

CARNEIRO DA CUNHA, Maria Manuela. 1978. Os mortos e os outros: uma análise do sistema funerário e da noção de pessoa entre os indios Krahó. São Paulo: Hucitec. - 1998. "Pontos de vista sobre a floresta amazônica: xamanismo e tradução". Mana: Estudos de Antropologia Social, 4(1):7-22.

CESARINO, Pedro N. 2008. Oniska A poética do mundo e da morte entre os Marubo da Amazônia ocidental. Tese de doutorado, PPGAS-Museu Nacional, Universidade Federal do Rio de Janeiro.

CHAUMEIL, Jean-Pierre. 1983. Voir, savoir, pouvoir. Le chamanisme chez les Yagua du nord-est péruvien. Paris: École des Hautes Études en Sciences Sociales.

Clastres, Pierre. 1978. A sociedade contra o Estado. Rio de Janeiro: Francisco Alves. 
- 1982. Arqueologia da violência: ensaios de antropologia política. São Paulo: Brasiliense.

CLENDINNEN, Inga. 1991. Aztecs: an interpretation. Cambridge: Cambridge University Press.

COELHO DE SOUZA, Marcela \& FAUSTO, Carlos. 2004. "Reconquistando o campo perdido: o que Lévi-Strauss deve aos ameríndios". Revista de Antropologia, 47(1):87-131.

COLLET, Celia. 2006. Rituais da civilização, rituais da cultura: a escola entre os Bakairi. Tese de doutorado, PPGAS-Museu Nacional, Universidade Federal do Rio de Janeiro.

COLLIER, Jane F. \& ROSALDO, Michelle Z. 1981. "Politics and gender in simple societies". In: S. Ortner \& H. Whitehead (orgs.), Sexual meanings. Cambridge: Cambridge University Press. pp. 275-329.

COMBÈS, Isabelle. 2005. Etno-historias del Isoso: Chané y Chiriguanos en el Chaco boliviano (siglos XVI a XX). La Paz: Fundación PIEB; IFEA.

COMBÈS, Isabelle \& LOWREY, Kathleen. 2006. "Slaves without masters? Arawakan dynasties among the Chiriguano". Ethnohistory, 53(4):689714.

. \& Saignes, Thierry. 1991. Alter ego: naissance de l'identité chiriguano. Paris: Editions de l'École des Hautes Études en Sciences Sociales.

_ \& Villar, Diego. 2004. "Aristocracias chané: 'casas' en el Chaco argentino y boliviano". Journal de la Société des Américanistes, 90(2):63-102.

CORMIER, Loretta A. 2003. Kinship with monkeys: the Guajá foragers of eastern Amazonia. New York: Columbia University Press.

COSTA, Luiz Antonio. 2007. As faces do jaguar. Parentesco, história e mitologia entre os Kanamari da Amazônia Ocidental. Tese de Doutorado,
PPGAS-Museu Nacional, Universidade Federal do Rio de Janeiro.

. 2008. "Our body is our owner and our chief". Séminaire des Américanistes. EHESS, Paris. Ms.

DAILLANT, Isabelle. 1998. "'Ils sont comme nous, mais...' Relations de parenté et de genre entre Chimane et 'gens du dedans'". Anthropologie et Société, 22(2):75-97.

- 2003. Sens dessus dessous: organisation sociale et spatiale des chimane d'Amazonie bolivienne. Nanterre: Société d'ethnologie.

D'ANGLURE, Bernard Saladin \& MORIN, Françoise. 1998. "Marriage mystique et pouvoir chamanique chez les Shipibo et les Inuit". Anthropologie et Sociétés, 22(2):49-74.

DÉLÉAGE, Pierre. 2005. Le chamanisme sharanahua: enquête sur l'apprentissage et l'épistémologie d'un rituel. Thèse de doctorat, Paris, EHESS.

DELEUZE, Gilles. 1968. Spinoza et le problème de l'expression. Paris: Éditions de Minuit.

DESCOLA, Philippe. 1986. La nature domestique: symbolisme et praxis dans l'écologie des Achuar. Paris: Maison des Sciences de l'Homme.

. 1993. "Les affinités sélectives: alliance, guerre et prédation dans l'ensemble jivaro". L'Homme, XXXIII(2-4):171190.

. 1994. "Pourquoi les indiens d'Amazonie n'ont-ils pas domestiqué le pécari? Genéalogie des objets et anthropologie de l'objectivation". In: B. Latour \& P. Lemonnier (orgs.), De la préhistoire aux missiles balistiques: l'intelligence sociale des techniques. Paris: La Découverte. pp. 329-344.

. 2001. "The genres of gender: local models and global paradigms in the comparison of Amazonia and Melanesia". In: T. G. A. D. Tuzin (org.), 
Gender in Amazonia and Melanesia: an exploration of the comparative method. Berkeley: University of California Press. pp. 244-278.

DESCOMBES, Vincent. 1979. Le même et l'autre: quarante-cinq ans de philosophie française (1933-1978). Paris: Minuit.

DUMONT, Louis. 1975. Dravidien et Kariera: l'alliance de mariage dans l'Inde du Sud et en Australie. La Haye: Mouton.

DREYFUS, Simone. 1993. "Systèmes dravidiens à filiation cognatique en Amazonie". L'Homme, XXXIII (2-4):121-140.

ERIKSON, Philippe. 1986. "Alterité, tatouage et anthropophagie chez les Pano: la belliqueuse quête de soi". Journal de la Société des Américanistes, LXII:185-210.

- 1987. "De l'apprivoisement à l'approvisionnement: chasse, alliance et familiarisation en Amazonie amérindienne". Techniques et Cultures, 9:105-140.

. 2000. "The social significance of petkeeping among Amazonian Indians". In: A. Podberscek; E. Paul \& J. Serpell (orgs.), Companion animals and us: exploring the relationships between people and pets. Cambridge: Cambridge University Press. pp. 7-26.

FAUSTO, Carlos. 1991. Os Parakanã: casamento avuncular e dravidianato na Amazônia. Dissertação de Mestrado, PPGAS-Museu Nacional, UFRJ.

- 1997. A dialética da predação e da familiarização entre os Parakanã da Amazônia oriental: por uma teoria da guerra ameríndia. Tese de doutorado, Rio de Janeiro, PPGAS-Museu Nacional, UFRJ.

. 1999a. "Of enemies and pets: warfare and shamanism in Amazonia". American Ethnologist, 26(4):933-956. 1999b. "Da inimizade: forma e simbolismo da guerra indígena". In: Adauto, Novaes (org.), A outra margem do Ocidente. São Paulo: Companhia das Letras. pp. 251-282.

2001a. Inimigos fiéis: história, guerra e xamanismo na Amazônia. São Paulo, Brasil: Edusp.

. 2001b. "La conversion des ennemis: un rêve amazonien". Texto apresentado na École Pratiques des Hautes Études, Paris. Ms.

2002a. "Banquete de gente: comensalidade e canibalismo na Amazônia". Mana. Estudos de Antropologia Social, 8(2):7-44.

. 2002b. "The bones affair: knowledge practices in contact situations seen from an amazonian Case". Journal of the Royal Anthropological Institute, 8(4):669-690.

- 2002c. "Faire le mythe: histoire, récit et transformation en Amazonie". Journal de la Société des Américanistes, 88:69-90.

2007. "Feasting on people: cannibalism and commensality in Amazonia". Current Anthropology, 48(4):497530.

; FRANCHETTO, Bruna \& MONTAGNANI, Tommaso. 2007. "Les formes de la mémoire: arts verbaux et musique chez les Kuikuro du Haut Xingu". Texto apresentado na École des Hautes Études en Sciences Sociales, Paris. Ms.

FRANCHETTO, Bruna. 1993. "A celebração da história nos discursos cerimoniais kuikúru (Alto Xingu)". In: M. Carneiro da Cunha \& E. Viveiros de Castro (orgs.), Amazônia: etnologia e história indígena. São Paulo: Núcleo de História Indígena e do Indigenismo da USP/FAPESP. pp. 95-116.

GALLOIS, Dominique. 1984/1985. "O pajé wayãpi e seus espelhos". Revista de Antropologia, 27/28:179-196. 
- 1988. O movimento na cosmologia waiãpi: criação, expansão e transformação do mundo. Tese de Doutorado, São Paulo, Universidade de São Paulo.

. 1996. "Xamanismo waiãpi: nos caminhos invisíveis, a relação I-Paie". In: J. Langdon (org.), Xamanismo no Brasil: novas perspectivas. Florianópolis: UFSC. pp. 39-74.

GELL, Alfred. 1998. Art and agency: an anthropological theory. Oxford: Clarendon Press.

GORDON, Cesar. 2006. Economia selvagem: ritual e mercadoria entre os índios Xikrin-Mebêngôkre. São Paulo: Editora UNESP; Instituto Socioambiental; Núcleo de Transformações Indígenas.

GOW, Peter. 1994. "River people: shamanism and history in western Amazonia". In: N. Thomas \& C. Humphrey (orgs.), Shamanism, history and the state. Ann Arbor: Michigan University Press. pp. 90-113.

- 1999. "Piro designs: painting as meaningful action in an amazonian lived world". Journal of the Royal Anthropological Institute, 5(2):229-246.

- 2001. An amazonian myth and its history. Oxford; New York: Oxford University Press.

GRAY, Andrew. 1997. The last shaman: change in an amazonian community. Providence, RI: Bergham Books.

GREGOR, Thomas. 1977. Mehinaku: the drama of daily life in a brazilian indian village. Chicago: The University of Chicago Press.

GUSS, David M. 1989. To weave and sing: art, symbol, and narrative in the South American rain forest. Berkeley: University of California Press.

HAMAYON, Roberte. 1990. La chasse à l'âme. Paris: Mémoires de la Société d'Ethnologie, Nanterre.

HECKENBERGER, Michael. 2002. "Rethinking the arawakan diaspora: hierarchy, regionality, and the amazonian formative". In: J. D. Hill \& F. Santos-Granero (orgs.), Comparative arawakan histories: rethinking language family and culture area in Amazonia. Urbana: University of Illinois Press. pp. 99-122.

- 2005. The ecology of power: culture, place, and personhood in the southern Amazon, AD 1000-2000. New York: Routledge.

HENRY, Jules 1964. Jungle people: a kaigang tribe of the highlands of Brazil. New York: Vintage Book.

HUGH-JONES, Stephen. 1988. "The gun and the bow: myths of white men and Indians". L'Homme, XXVIII(23):138-155.

- 1994. "Shamans, prophets, priests and pastors". In: N. Thomas \& C. Humphrey (orgs.), Shamanism, history and the state. Ann Arbor: Michigan University Press. pp. 32-75. . 1996. "Bonnes raisons ou mauvaise conscience? De l'ambivalence de certains amazoniens envers la consommation de viande". Terrain, 26:123-148.

HULTKRANTZ, Ake. 1961. "The owner of the animals in the religion of north american Indians". In: A. Hultcrantz (org.), The supernatural owners of nature. Stockholm: Almqvist and Wiksell. pp. 53-64.

JAMOUS, Raymond. 1991. La relation frère-sœur: parenté et rites chez les Meo de l'Inde du Nord. Paris: Editions de l'Ecole des Hautes Études en Sciences Sociales.

KANT, Immanuel. 1985. "Idea for a universal history from a cosmopolitan point of view". On history. 5.ed. Trad: Lewis White Beck. Indianapolis: Bobbs-Merril. pp. 11-26

KARADIMAS, Dimitri. 2001. "Parenté en esclavage. Pratiques matrimoniales et alliances politiques chez les Mi- 
raña d'Amazonie colombienne". Droit et Cultures, 39:81-100.

. 2005. La raison du corps: idéologie du corps et représentations de l'environnement chez les Miraña d'Amazonie colombienne. Paris: Peeters.

KELLY, Raymond. 1993. Constructing inequality: the fabrication of a hierarchy of virtue among the Etoro. Ann Arbor: University of Michigan Press.

KOHN, Eduardo. 2002. Natural engagements and ecological aesthetics among the Avila Runa of amazonian Ecuador. Doctoral thesis. Madison, University of Wisconsin.

- 2007. "Animal masters and the ecological embedding of history among the Ávila Runa of Ecuador" In: Carlos Fausto \& Michael Heckenberger (orgs), Time and memory in indigenous Amazonia: anthropological perspectives. Gainesville: University Press of Florida. pp. 106-129.

LARRABEE, Mary J. 1993. An ethic of care: feminist and interdisciplinary perspectives. New York: Routledge.

LÉVI-STRAUSS, Claude. 1943. "The social use of kinship terms among brazilian Indians". American Anthropologist, 45:398-409.

- 1964. Mythologiques: le cru et le cuit. Paris: Plon. - 1991. Histoire de lynx. Paris: Plon.

LLOYD THOMAS, D. A. 1995. Locke: on government. London: Routledge.

LOCKE, John. 1988 [1689]. Two treatises of government. Cambridge: Cambridge University Press.

- 1995 [1691]. An essay concerning human understanding. Oxford: Clarendon Press.

MACHADO, Maria de Fátima. 1994. Índios de Rondon: Rondon e as linhas telegráficas na visão dos sobreviventes Wáimare e Kaxíiti, grupos paresi. Tese de Doutorado, PPGAS-Museu Nacional, UFRJ.
MACINTYRE, Alasdair C. 1981. After virtue: a study in moral theory. Notre Dame, Ind.: University of Notre Dame Press.

MAIA FIGUEIREDO, Paulo Roberto. 2007. Santos e Jurupari: a matéria da relação no alto rio Negro. Etnografia da festa e do ritual com os Baré. Exame de Qualificação de Doutorado, PPGAS-Museu Nacional, UFRJ. Ms. 148 pp.

MENGET, Patrick. 1977. Au nom des autres: classification des relations sociales chez les Txicão du Haut-Xingu. Thèse de $3^{\text {eme }}$ cycle, Université de Paris-X.

. 1988. "Note sur l'adoption chez les Txicão du Brésil Central". Anthropologie et Sociétés, 12(2):63-72.

MILLER, Joana. 2007. As coisas: enfeites corporais e a noção de pessoa entre os Mamaindê (Nambiquara). Tese de Doutorado, PPGAS-Museu Nacional, UFRJ.

MURA, Fábio. 2006. À procura do "bom viver": território, tradição de conhecimento e ecologia doméstica entre os Kaiowá. Tese de Doutorado, PPGAS-Museu Nacional, UFRJ.

MURPHY, Robert. 1958. Mundurucu religion. Berkeley: University of California Press.

OVERING KAPLAN, Joanna. 1975. The Piaroa: a people of the Orinoco basin: a study in kinship and marriage. Oxford: Clarendon Press. . 1984. "Dualisms as an expression of difference and danger: marriage exchange and reciprocity among the Piaroa of Venezuela". In: K. Kensinger (org.), Marriage practices in Lowland South America. Illinois: University of Illinois Press. pp. 127-155. . 1999. "O elogio do cotidiano: a confiança e a arte da vida social em uma comunidade amazônica". Mana. Estudos de Antropologia Social, 5(1):81107. 
RAMOS, Alcida R.; SILVERWOOD-COPE, Peter \& OLIVEIRA, Ana Gita de. 1980. "Patrões e clientes: relações intertribais no Alto Rio Negro". In: A. Ramos (org.), Hierarquia e simbiose: relações intertribais no Brasil. São Paulo: Hucitec. pp. 135-182.

RICOEUR, Paul. 1990. Soi-même comme un autre. Paris: Seuil.

RIVIÈRE, Peter. 1969. Marriage among the Trio: a principle of social organization. Oxford: Clarendon Press. - 1984. Individual and society in Guiana: a comparative study of amerindian social organization. Cambridge: Cambridge University Press.

. 1987. "Of women, men and manioc". In: H. O. Ska \& F. Salomon (orgs.), Natives and neighbours in South America: anthropological essays. Gottemburg: Ethnographic Museum. pp. 178-201.

RODGERS, David. 2002. "A soma anômala: a questão do suplemento no xamanismo e menstruação ikpeng". Mana. Estudos de Antropologia Social, 8(2):91-125.

SANTOS-GRANERO, Fernando. 2002. "The arawakan matrix: ethos, language, and history in native South America". In: J. D. Hill \& F. SantosGranero (orgs.), Comparative arawakan histories: rethinking language family and culture area in Amazonia. Urbana: University of Illinois Press. pp. 25-50.

- 2005. "Amerindian torture revisited: rituals of enslavement and markers of servitude in tropical America". Tipití, 3(2):147-174.

- (no prelo). Vital enemies: slavery, predation and the amerindian political economy of life. Austin, TX: The University of Texas Press.

SEVERI, Carlo. 2007. Le principe de la chimère: une anthropologie de la mémoire. Paris: Presses de l'Ecole
Normale Supérieure / Musée du Quai Branly.

SEEGER, Anthony. 1981. Nature and society in Central Brazil: the Suyá indians of Mato Grosso. Cambridge, MS: Harvard University Press.

STADEN, Hans. 1974 [1557]. Duas viagens ao Brasil. Belo Horizonte: Itatiaia.

STERPIN, Adriana. 1993. "La chasse aux scalps chez les Nivacle du Gran Chaco". Journal de la Société des Américanistes, LXXIX:33-66.

STRATHERN, Marilyn. 1988. The gender of the gift: problems with women and problems with society in Melanesia. Berkeley: University of California Press.

. 1992. "Parts and wholes: refiguring relationship in a post-plural world". In: Adam Kuper (org.), Conceptualizing society. London: Routledge. pp. 75-104.

- 1999. Property, substance and effect: anthropological essays on persons and things. London: The Athlone Press.

2005. Kinship, law and the unexpected: relatives are always a surprise. New York, NY: Cambridge University Press.

SURRALLÉS, Alexandre. 2003. Au coeur du sens: perception, affectivité, action chez les Candoshi. Paris: Maison des Sciences de L'Homme/ CNRS.

SZTUTMAN, Renato. 2005. O profeta e o principal: a ação política ameríndia e seus personagens. Tese de Doutorado, Departamento de Antropologia, Universidade de São Paulo.

TAYLOR, Anne-Christine. 1983. "The marriage alliance and its structural variations in jivaroan societies". Social Science Information, 22(3):331353.

. 1985. "L'art de la réduction. La guerre et les mécanismes de la différencia- 
tion tribal dans la culture Jíbaro". Journal de la Société des Américanistes, LXXI:159-173.

. 1989. "La parenté jívaro: une variante riche". Ms.

- 1993. "Des fantômes stupéfiants: langage et croyance dans la pensée achuar". L'Homme, 126-128:429448.

. 1994. "Les bons ennemis et les mauvais parents: le traitement symbolique de l'alliance dans les rituels de chasse aux têtes des Jivaros de lEquateur". In: E. Copet \& F. Héritier-Augé (orgs.), Les complexités de l'alliance, IV. Paris: Archives Contemporaines. pp. 73-105.

- 2000. "Le sexe de la proie. Représentations jivaro du lien de parenté". L'Homme, 154-155:309-333.

- 2003. "Les masques de la mémoire. Essai sur la fonction des peintures corporelles jíbaro". L'Homme, 164:223-248.

TEIXEIRA-PINTO, Márnio. 1997. Ieipari: sacrifício e vida social entre os índios Arara (Caribe). São Paulo, Curitiba: Editora Hucitec / ANPOCS / Editora UFPR.

TOLA, Florencia. 2006. "Une agentivité decentrée du sujet ou comment les Toba du Gran Chaco interagissent avec les esprits-maîtres des espèces". Texto apresentado no seminário do grupo de pesquisa "L'agentivité: les esprits-maîtres". Paris: Équipe de Recherche en Ethnologie Amérindienne. Ms.

TULLY, James. 1993a. "After the Macphersons thesis". In: An approach to political philosophy: Locke in contexts. Cambridge: Cambridge University Press. pp. 71-95. . 1993b. "The framework of natural rights in Locke's analysis of property". In: An approach to political philosophy: Locke in contexts. Cam- bridge: Cambridge University Press. pp. 96-117.

TURNER, Terence. 1979. “The gê and bororo societies as dialectical systems: a general model". In: D. MayburyLewis (org.), Dialectical societies: the Gê and Bororo of Central Brazil. Cambridge, Mass.: Harvard University Press. pp. 145-178.

- 1991. "The Mebengokre Kayapo: history, social consciousness and social change. From autonomous communities to inter-ethnic system". Ms.

VElTHEM, Lucia Hussak van. 2003. O Belo é a fera: a estética da produção e da predação entre os Wayana. Lisboa: Museu Nacional de Etnologia/ Assírio \& Alvim.

VERSWIJVER, Gustaaf. 1992. The club-fighters of the Amazon. Warfare among the Kayapo Indians of Central Brazil. Gent: Rijksuniversiteit te Gent.

VILAÇA, Aparecida. 1992. Comendo como gente: formas do canibalismo wari' (Pakaa-Nova). Rio de Janeiro: Editora da UFRJ.

· 1996. "Cristãos sem fé: alguns aspectos da conversão dos Wari (Pakaa Nova)". Mana. Estudos de Antropologia social, 2(1):109-137.

- 2006. Quem somos nós: os Wari' encontram os brancos. Rio de Janeiro: Editora da UFRJ.

VIVEIROS DE CASTRO, Eduardo. 1986. Araweté: os deuses canibais. Rio de Janeiro: J. Zahar / Associação Nacional de Pós Graduação e Pesquisa em Ciências Sociais.

-1992. From the enemy's point of view: humanity and divinity in an amazonian society. Chicago: University of Chicago Press.

. 1993. "Alguns aspectos da afinidade no dravidianato amazônico". In: M. Carneiro da Cunha \& E. Viveiros de Castro (orgs.), Amazônia: etnologia e história indígena. São Paulo: Núcleo 
de História Indígena e do Indigenismo da USP/ FAPESP. pp. 149-210.

. 1998. "Cosmological perspectivism in Amazonia and elsewhere". In: Simon Bolivar Lectures, Department of Social Anthropology. University of Cambridge. Ms.

- 2002a. "Esboço de cosmologia yawalapíti". In: A inconstância da alma selvagem. São Paulo: Cosac \& Naify. pp. 25-85.

. 2002b. "Perspectivismo e naturalismo na Amazônia indígena". In: A inconstância da alma selvagem. São Paulo: Cosac \& Naify. pp. 345-399. . 2002c. "Xamanismo e sacrifício". In: A inconstância da alma selvagem. São Paulo: Cosac \& Naify. pp. 457-472.

. 2007. "Filiação intensiva e aliança demoníaca". Novos Estudos do Cebrap, 77:91-126.

WAGLEY, Charles 1976. "Xamanismo tapirapé". In: E. Schaden (org.), Leituras de etnologia brasileira. São Paulo: Companhia Editora Nacional. pp. 236-267.

WAGNER, Roy. 1991. "The fractal person". In: Maurice Godelier \& Marilyn Strathern (orgs.), Big men and great men: personifications of power in Melanesia. Cambridge: Cambridge University Press. pp. 159-173.

WEBER, Max. 1984 [1922]. Economia y sociedad: esbozo de sociologia comprensiva. Mexico: Fondo de Cultura Económica. 
Resumo

O texto versa sobre certa categoria indígena - usualmente traduzida por "dono" ou "mestre" - que, na Amazônia, transcende em muito a simples expressão de uma relação de propriedade ou domínio. A categoria e seus recíprocos designam um modo generalizado de relação, que caracteriza interações entre humanos, entre não-humanos, entre humanos e não-humanos e entre pessoas e coisas. Trata-se de uma categoria-chave para a compreensão da sociologia e da cosmologia indígenas que, não obstante, recebeu relativamente pouca atenção. Esse texto visa explorar, a partir de um conjunto de evidências etnográficas, as conseqüências de imaginar-se o universo ameríndio como um mundo de donos e o dono como o modelo da pessoa magnificada, com o objetivo de discutir noções de posse, domínio e poder nas terras baixas da América do Sul.

Palavras-chave Amazônia, Propriedade, Poder, Pessoa, Individualismo

\section{Abstract}

This text is concerned with a specific Indigenous category - usually translated as "owner" or "master" - which, in Amazonia, transcends the simple expression of a relationship of property or domain. The category and its reciprocal terms designate a generalized mode of relating that characterizes interactions between humans, between non-humans, between humans and non-humans and between persons and things. It is a key category for understanding Indigenous sociologies and cosmologies, which, notwithstanding its importance, has received relatively little attention. Through the analysis of ethnographical evidence, this text seeks to explore the consequences of imagining the Amerindian universe as a world of owners and the owner as a model for the magnified person, in order to discuss notions of ownership, domain and power in lowland South America.

Key words Amazonia, Property, Power, Person, Individualism 